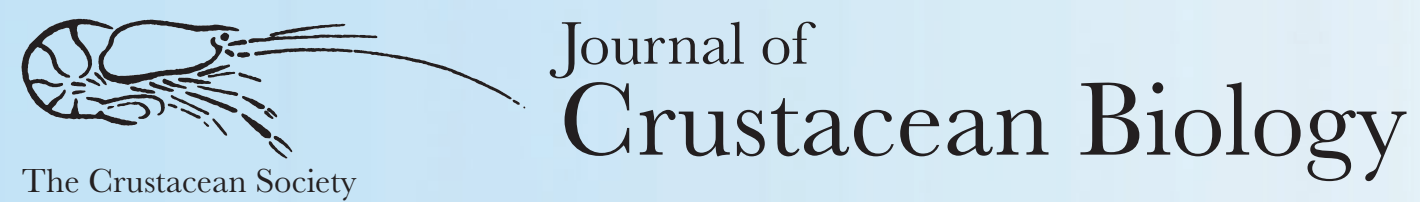

Journal of Crustacean Biology (2021) 41(3), 1-17. https://doi.org/10.1093/jcbiol/ruab046

\title{
Standing stock of Antarctic krill (Euphausia superba Dana, 1850) (Euphausiacea) in the Southwest Atlantic sector of the Southern Ocean, 2018-19
}

Bjørn A. Krafft ${ }^{1, \oplus}$, Gavin J. Macaulay ${ }^{1, \odot}$, Georg Skaret $^{1, \odot}$, Tor Knutsen ${ }^{1, \odot}$, Odd A. Bergstad ${ }^{1}$,

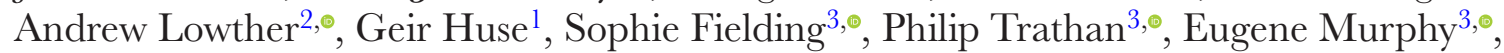
Seok-Gwan Choi ${ }^{4}$, Sangdeok Chung ${ }^{4}$, Inwoo Han ${ }^{4}$, Kyounghoon Lee ${ }^{5}$, Xianyong Zhao ${ }^{6}$, Xinliang Wang ${ }^{6, \oplus}$, Yiping Ying ${ }^{6}, X$ iaotao $\mathrm{Yu}^{6, \oplus}$, Kostiantyn Demianenko $^{7}$, Viktor Podhornyi ${ }^{7}$, Karina Vishnyakova $^{8, \oplus}$, Leonid Pshenichnov ${ }^{7}$, Andrii Chuklin ${ }^{9}$, Hanna Shyshman ${ }^{9}$, Martin J. Cox ${ }^{10}$, Keith Reid $^{11}$, George M. Watters ${ }^{12, \oplus}$, Christian S. Reiss ${ }^{12}$, Jefferson T. Hinke ${ }^{12, \oplus}$, Javier Arata ${ }^{13, \oplus,}$ Olav R. Godø ${ }^{14, \bullet}$ and Nils Hoem ${ }^{14}$

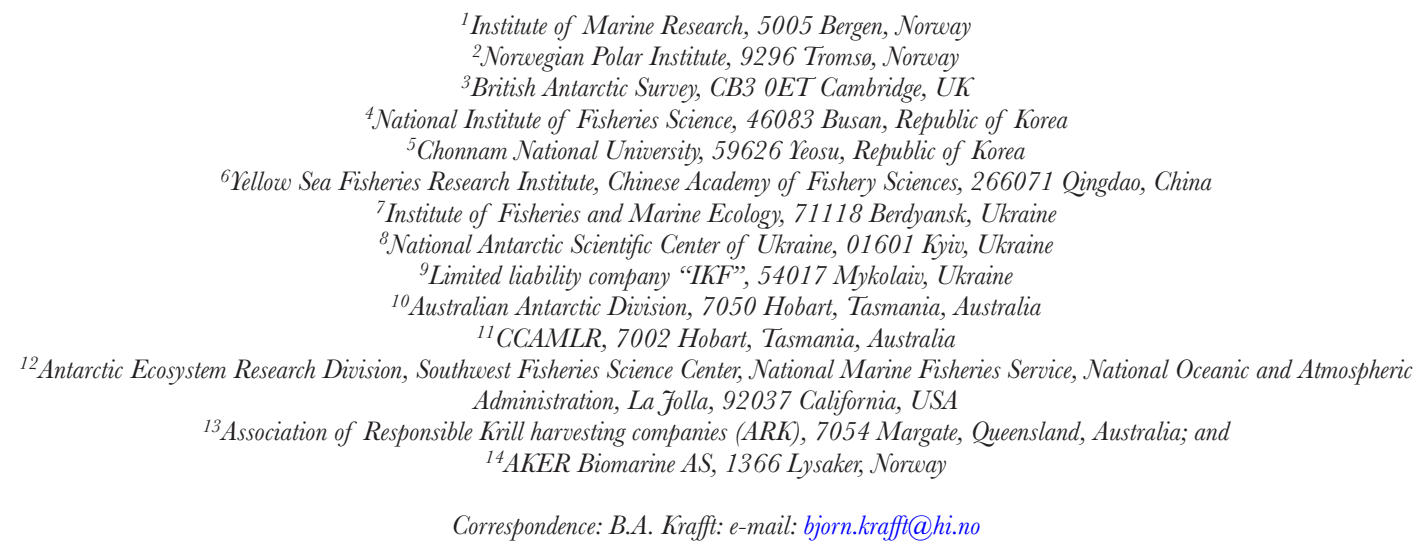

(Received 27 April 2021; accepted 26 August 2021)

\begin{abstract}
Estimates of the distribution and density of Antarctic krill (Euphausia superba Dana, 1850) were derived from a large-scale survey conducted during the austral summer in the Southwest Atlantic sector of the Southern Ocean and across the Scotia Sea in 2018-19, the '2018-19 Area 48 Survey'. Survey vessels were provided by Norway, the Association of Responsible Krill harvesting companies and Aker BioMarine AS, the United Kingdom, Ukraine, Republic of Korea, and China. Survey design followed the transects of the Commission for the Conservation of Antarctic Marine Living Resources synoptic survey, carried out in 2000 and from regular national surveys performed in the South Atlantic sector by the U.S., China, Republic of Korea, Norway, and the U.K. The 2018-19 Area 48 Survey represents only the second large-scale survey performed in the area and this joint effort resulted in the largest ever total transect line $(19,500 \mathrm{~km})$ coverage carried out as one single exercise in the Southern Ocean. We delineated and integrated acoustic backscatter arising from krill swarms to produce distribution maps of krill areal biomass density and standing stock (biomass) estimates. Krill standing stock for the Area 48 was estimated to be 62.6 megatonnes (mean density of $30 \mathrm{~g} \mathrm{~m}^{-2}$ over 2 million $\mathrm{km}^{2}$ ) with a sampling coefficient variation of $13 \%$. The highest mean krill densities were found in the South Orkney Islands stratum $\left(93.2 \mathrm{~g} \mathrm{~m}^{-2}\right)$ and the lowest in the South Georgia Island stratum $\left(6.4 \mathrm{~g} \mathrm{~m}^{-2}\right)$. The krill densities across the strata compared to those found during the previous survey indicate some regional differences in
\end{abstract}


distribution and biomass. It is currently not possible to assign any such differences or lack of differences between the two survey datasets to longer term trends in the environment, krill stocks or fishing pressure.

Key Words: acoustic survey, biomass, climate, ecosystem change, fishery management, global climate change, zooplankton

\section{INTRODUCTION}

Antarctic krill (Euphausia superba Dana 1850, hereafter krill) are a key component in the Antarctic marine ecosystem and constitute an important fishery resource (Nicol et al., 2012). The fishery for krill is managed by the Commission for the Conservation of Antarctic Marine Living Resources (CCAMLR). Krill catch is controlled through mass-based quotas. A fixed precautionary annual catch limit for the Southwest Atlantic sector was set to $620,000 \mathrm{t}$ (termed the 'trigger level') by CAAMLR in 1991 (CCAMLR Conservation measure 51-01). This arbitrary precautionary catch limit was established to avoid potential negative effects on the krill population and krill-dependent predators and are based on data from historical catches. This precautionary catch limit was subdivided in 2009 within the Food and Agriculture Organization (FAO) Statistical Subareas $48.1,48.2,48.3$, and 48.4 to avoid inadvertent ecosystem effects of concentrated fishing (CCAMLR Conservation measure 51-07). The biomass of krill for the region where commercial fishing operates (Subareas 48.-48.4; Fig. 1) was estimated to be 60.3 megatonnes with a sampling coefficient of variation (CV) of 13\% (CCAMLR, 2010). This biomass estimate was based on a 2010 re-analysis (CCAMLR 2010; Fielding et al., 2011, Nicol et al., 2012) of the CCAMLR-2000 Krill Synoptic Survey (Hewitt et al., 2004; Watkins et al., 2004), hereafter the CGAMLR 2000 survey. Two major multi-ship campaigns, FIBEX (First International BIOMASS Experiment) in 1980-1981 (El-Sayed, 1994) and SIBEX (Second International BIOMASS Experiment II (SIBEX II) in 1983-1984 and 1984-1985 (Siegel, 1986; Trathan et al., 1993, 1995; El-Sayed, 1994; Hosie, 2012) have also been performed in the Southwest Atlantic sector, but data are in need of reprocessing to enable comparisons to the CCAMLR 2000 survey. The CGAMLR 2000 survey was the only previous large-scale effort to achieve comprehensive spatial coverage of krill biomass distribution in the SW Atlantic sector (CCAMLR Area 48). Using a singlespecies stock assessment model (Generalised Yield Model; Constable \& de la Mare, 1996), a total allowable catch limit (TAC) of krill for the Areas 48.1-48.4, based on the CGAMLR 2000 survey, was estimated to be 5.61 million t. While the TAC was amended in 2010, the trigger level and the precautionary catch limits within the subareas have remained in place.

One evaluation of the management of krill in the Atlantic sector of the Southern Ocean has been made by comparing recent catches to regional biomass estimates (Hill et al., 2016). Such regional estimates are made as part of local monitoring programs in the main fishing areas off South Georgia Island (Fielding et al., 2014), the South Orkney Islands (Krafft et al., 2018a), and the South Shetland Islands (Reiss et al., 2008). These regional surveys highlight the variable nature of krill stocks, but their limited spatial scope precludes advice on the overall status of the krill population. Conservative estimates from these meso-scale surveys suggest that fishing near the precautionary catch limits within the subareas is sufficiently precautionary to maintain the krill stock (Hill et al., 2016). As the time series from these smaller scaled surveys build up and models and methods standardize results, they potentially become increasingly pertinent for considering the wider connectivity between regions (Brierley et al., 1999) and to provide data to regularly update fisheries regulations. There is also an active debate about effects of the fishery, and there are models and empirical studies that indicate plausible negative impacts from spatiotemporally concentrated fishing on the breeding success of land-based krill-dependent predators on small scales (Krüger et al., 2020; Watters et al., 2013, 2020). Historical krill distribution and abundance have also been analysed from net sample data (Atkinson et al., 2017, 2019; Cox et al., 2018; Hill et al., 2019) to examine krill population trends over longer periods across the Southwest Atlantic sector. Net sampling of krill in this area goes back to the 1920s, but samples are strongly uneven in space and time, and have not always been collected with the same standard sampling strategy, which makes analysis challenging and may cause divergent results (Cox et al., 2018, 2019; Hill et al., 2019).

There is ongoing work in CCAMLR towards developing an adaptive and dynamic feedback management (FBM) approach for the krill fishery (CCAMLR, 2017) to enable faster management response to various types of ecosystem change. The development towards this operational FBM scheme requires method development and integration of data collected by various collection platforms from different spatial and temporal scales. As the current catch limits in place for the krill fishery are not directly related to the actual stock status, an FBM system should aim to balance dynamically rational utilization of resources while satisfying the conservation objective of the Convention (Hewitt \& Low, 2000). Development towards more long-term dynamic fishery management principles allows for regular updating of catch allocation and precautionary catch limits set for even smaller scales than the current subarea scale (e.g., Constable \& Nicol, 2002; Heywood et al., 2006). The dynamic nature of krill must also be considered with changing distribution patterns during the season which can be variable and difficult to predict. The FBM strategy requires, inter alia, fundamental knowledge and improved understanding of krill biology, population dynamics, spatial distribution, and their interspecific and environmental synergies on multiple spatiotemporal scales.

Updating large-scale estimates of krill biomass and distribution of krill in the Southwest Atlantic sector has the potential to guide the establishment of a future time series that contributes to the evaluation of impacts on krill that arise from long-term global trends (IPCC, 2018), including effects on the sustainability of its exploitation and relation to the recovery of historically depleted predator populations (Zerbini et al., 2019). In this regard, a new, large-scale survey of krill biomass in Area 48 was conducted in the austral summer of 2018-2019. The overall aims for this publication are to: 1) provide an overall reference, in terms of density and distribution, for krill within the survey area that will be valuable for comparisons with annual, mesoscale surveys undertaken at South Georgia (Fielding et al., 2014), the South Orkney Islands (Krafft et al., 2018a), and near the Antarctic Peninsula (Reiss et al., 2008); and 2) provide information pertinent to update TAC and future spatial management considerations.

We provide a detailed description of the survey rationale, protocols, and collection methods used, which contrast with Trathan et al. (2001). Estimates of the large-scale krill biomass are presented, as well as per stratum estimates, with associated uncertainties. Some comparisons of our survey methods and results with the CCAMLR 2000 survey are also presented. Finally, we provide an estimate of krill biomass, using the 2018-19 Area 48 Survey methods, for comparison with the ongoing regional and national surveys. 


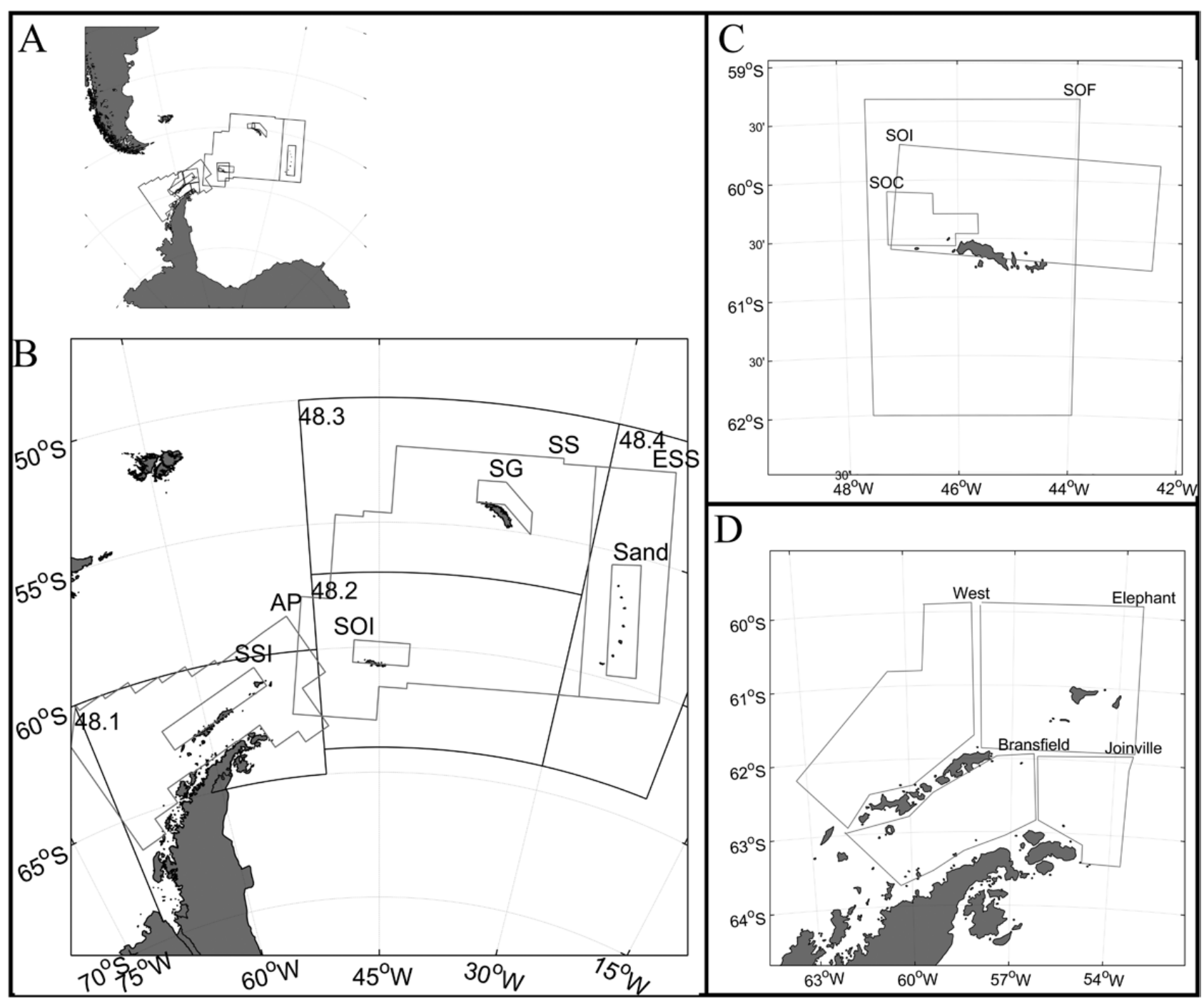

Figure 1. Overview of the survey area, CCAMLR area designations (A), with labels 48.1, 48.2, 48.3, and 48.4 and strata (SS, Scotia Sea; AP, Antarctic Peninsula; SSI, South Shetland Islands; SOI, South Orkney Islands; Sand, South Sandwich Islands; SG, South Georgia Island; ESS, Eastern Scotia Sea) (B); SOI, South Orkney Islands; SOF, South Orkney fixed; SOC, South Orkney concentrated $(\mathbf{C})$, AMLR strata $(\mathbf{D})$.

\section{MATERIAL AND METHODS}

A ship-based acoustic survey was carried out in the Southwest Atlantic sector of the Southern Ocean, primarily within CCAMLR Subareas 48.1, 48.2, 48.3, and 48.4 (Fig. 1).

\section{Vessels, timing, transects and area covered}

Most of the survey effort (approximately 13,600 km of transects) was allocated to repeat the transects and stations within the strata from the CGAMLR 2000 survey (Trathan et al., 2001; Watkins et al., 2004). This part of the survey was done by four vessels provided by Norway (RV Kronprins Haakon), Ukraine (FV More Sodruzhestva), the U.K. (RRS Discovery), and ARK \& Aker Biomarine AS (FV Cabo de Hornos) (Table 1).

Effort was also allocated to cover regional-scaled surveys (approximately $4,570 \mathrm{~km}$ of transects), allocated to the USA's Antarctic Marine Living Resources (US AMLR) former survey around the South Shetland Islands (Kinzey et al., 2015), the regular Norwegian survey around the South Orkney Islands (Krafft et al., 2018a), and the regular survey to the north west of South Georgia carried out by the United Kingdom (Fielding et al., 2014). The data from the north west of South Georgia will be published separately and examined in a time series data perspective. These regional scaled surveys were made by three of the same vessels also doing the large-scale coverage, provided by Norway, ARK/Aker, and the U.K. in addition two other vessels provided by China (FV Fu Rong Hai) and the Republic of Korea (FV Kwang $\mathrm{fa} \mathrm{Ho}_{\mathrm{o}}$ (Table 1).

The 2018-19 Area 48 Survey progressed along the same transects as the CCAMLR 2000 survey and was divided into one or more of the existing strata (Fig.1). For the CCAMLR 2000 survey these were the wider Antarctic Peninsula area and to the northwest of the South Shetland Islands in CCAMLR Subarea 48.1, the Southwest Atlantic sector around the South Orkney Islands and to the northeast of South Georgia in Subareas 48.2 and 48.3 respectively, and the Eastern Scotia Sea and around the South Sandwich Islands in Subarea 48.4. The additional survey effort was in the US AMLR strata termed West, Elephant, Bransfield, and Joinville; the Norwegian South Orkney Concentrated and South Orkney Fixed strata and the United Kingdom Western Core Box stratum to the north west of South Georgia. The vessels navigated as per the waypoints used for the CCAMLR 2000 survey (Trathan et al., 2001; Hewitt et al., 2004) and the regionalscale surveys (Fig. 1). Waypoint positions for the planned transects and stations were provided to each vessel (SG-CAMLR, 2018). 
B.A. KRAFFT ET AL.

Table 1. Vessel characteristics and equipment. For Echosounder particulars, the transceiver types were general purpose transceiver (GPT) and wideband transceiver (WBT). All echosounder and transducers were of the Simrad brand. *Krafft et al., 2018c; ** Baker et al., 1973; Roe \& Shale, 1979); *** Krag et al., 2014.

\begin{tabular}{|c|c|c|c|c|c|c|}
\hline Particular & $\begin{array}{l}\text { FV Cabo de } \\
\text { Hornos }\end{array}$ & RRS Discovery & FV Fu Rong Hai & RV Kronprins Haakon & FV Kwang Ja Ho & FV More Sodruzhestva \\
\hline \multicolumn{7}{|l|}{ Vessel characteristics } \\
\hline Flag & Chile & United Kingdom & China & Norway & Korea & Ukraine \\
\hline Type & Stern trawler & Research & Stern trawler & Research & Stern trawler & Stern trawler \\
\hline Year built & 1976 & 2013 & 1972 & 2018 & 1986 & 1986 \\
\hline Length (m) & 72 & 100 & 110 & 100 & 94 & 103 \\
\hline Breadth $(\mathrm{m})$ & 13.5 & 18 & 17.8 & 21 & 15.6 & 17.3 \\
\hline Engine power (kW) & 1912 & 7100 & 4190 & 17000 & 3601 & 5252 \\
\hline \multicolumn{7}{|l|}{ Krill sampling equipment } \\
\hline Gear type & $\begin{array}{l}\text { Macroplankton } \\
\text { trawl }\end{array}$ & RMT8+1** & $\begin{array}{l}\text { Commercial krill } \\
\text { trawl }\end{array}$ & Macroplankton trawl* & Commercial krill trawl & Commercial krill trawl \\
\hline Mouth opening & $36 m^{2}$ & $8 m^{2}$ & $900 \mathrm{~m}^{2}$ & $36 m^{2}$ & $750 \mathrm{~m}^{2}$ & $324 m^{2}$ \\
\hline $\begin{array}{l}\text { Multiple mesh netting } \\
\text { panels }\end{array}$ & no & no & yes & no & yes & yes \\
\hline $\begin{array}{l}\text { Codend mesh size }(\mathrm{mm}) \\
\text { (stretched, knot-knot) }\end{array}$ & $7 \mathrm{~S}, 3 \mathrm{~K}$ & $5 \mathrm{~K}$ & $15 S$ & 7S,3K & $12 S$ & $20 S$ \\
\hline Codend length (m) & & & 31 & & 23 & 49 \\
\hline Total gear length (m) & 42 & $\mathrm{n} / \mathrm{a}$ & 128.5 & 42 & 122 & 188 \\
\hline $\mathrm{L}^{50 * * *}(\mathrm{~mm})$ & 15.0 & 13.0 (6 mm mesh) & 31.9 & 15.0 & 25.7 & 41.6 \\
\hline \multicolumn{7}{|l|}{ Echosounder particulars } \\
\hline Software & EK80 & ER60 & ER60 & EK80 & ER60 & ES80 \\
\hline $\begin{array}{l}\text { Software/firmware } \\
\text { version }\end{array}$ & 1.12.2.0/2.20 & $2.4 .3 / 070413$ & $\mathrm{~N} / \mathrm{A}$ & 1.12.2/2.20 & 2.2.0/070413 & $\begin{array}{l}\text { 1.3.0.0/2.20 } \\
\text { (WBT)/070413 (GPT) }\end{array}$ \\
\hline $\begin{array}{l}\text { Transducer frequencies } \\
(\mathrm{kHz}) \text { and transceiver } \\
\text { type }\end{array}$ & 38, 120 (all WBT) & $\begin{array}{l}70,120,200 \text { (all } \\
\text { GPT) }\end{array}$ & $\begin{array}{l}38,70,120 \text { (all } \\
\text { GPT) }\end{array}$ & $\begin{array}{l}18,38,70,120,200 \\
333 \text { (all WBT) }\end{array}$ & 38, 120 (all GPT) & 120 (WBT), 200 (GPT) \\
\hline Transducer type & ES38B, ES120-7C & $\begin{array}{l}\text { ES70-7C, } \\
\text { ES120-7C, } \\
\text { ES200-7C }\end{array}$ & $\begin{array}{l}\text { ES38B, ES70-7C } \\
\text { ES120-7C }\end{array}$ & $\begin{array}{l}\text { ES18, ES38B, } \\
\text { ES70-7C, ES120-7C, } \\
\text { ES200-7C, ES333-7C }\end{array}$ & ES38B, ES120-7C & ES120-7C, ES200-7C \\
\hline $\begin{array}{l}\text { Transducer drop keel } \\
\text { available/used }\end{array}$ & no & yes/no & no & yes/yes & no & no \\
\hline Transducer locations & Near the bow & Mid-ships & Near the bow & Mid-ships & $\begin{array}{l}\text { Approx. } 1 / 3 \text { length } \\
\text { of the vessel from } \\
\text { the bow }\end{array}$ & $\begin{array}{l}\text { Approx. } 1 / 3 \text { length of } \\
\text { the vessel from the } \\
\text { bow }\end{array}$ \\
\hline $\begin{array}{l}\text { Transducer depth during } \\
\text { survey }(\mathrm{m})\end{array}$ & 4.0 & 6.6 & 5.0 & 11.2 & 5.0 & 7.0 \\
\hline
\end{tabular}

Deviations from the planned transects where necessary (e.g., icebergs, sea ice, safe navigation) were compensated for during statistical analysis (see below).

Vessels operated transects day and night (24-hour operation). This contrasts with the CCAMLR 2000 survey, where acoustic transects were only occupied between civil dawn and civil dusk (Watkins, et al., 2004). The effect of this difference in operational procedure was investigated by analysing the 2018-19 Area 48 Survey data twice, once using the full dataset and once using just the acoustic data collected during the civil day. For this, the elevation angle of the sun for the time and location of each acoustic integration interval was calculated (Meeus, 1998) and if it was greater than $-6^{\circ}$, marked as daylight.

\section{Acoustic equipment and settings}

All vessels used Simrad echosounders (EK60, ES80, or EK80 models) operating at narrowband frequencies through hull-mounted transducers (Table 1). RV Kronprins Haakon used a lowered transducer drop-keel to reduce the effect of near-surface bubbles; on all other vessels the transducers were at or near the hull level (Table 1) with fixed transducer depths ranging 5.0-11.2 $\mathrm{m}$ below the sea
Table 2. Prescribed echosounder configuration for survey and analysis.

\begin{tabular}{lcccc}
\hline Parameter/Frequency $(\mathrm{kHz})$ & 38 & 70 & 120 & 200 \\
\hline Transmit power $(\mathrm{W})$ & 2000 & 750 & 250 & 150 \\
Transmit pulse duration $(\mathrm{ms})$ & 1.024 & 1.024 & 1.024 & 1.024 \\
Acoustic absorption coefficient $(\mathrm{dB} / \mathrm{km})$ & 10.4 & 18.9 & 27.7 & 41.3
\end{tabular}

surface. The echosounder configuration was generally as specified by the survey instructions (Table 2; sound speed was set to $1456 \mathrm{~m}$ $\mathrm{s}^{-1}$ ). There were some unavoidable deviations in transmission power, sound speed, and acoustic absorption, due to different behaviours and design of the three echosounder models. To correct for this, sound speed and acoustic absorption were set to the recommended values during post-survey data processing, and differences in transmission power were accounted for from the calibration process.

\section{Calibrations}

All vessels were calibrated as per standard procedures (Demer et al., 2015) using $38.1 \mathrm{~mm}$ diameter tungsten carbide spheres. 
Where multiple calibrations were available, the one with the highest quality (lowest root-mean-square error) was used.

\section{Acoustic data processing}

The data from FV Cabo de Hornos, RV Kronprins Haakon, FV Kwang fa $\mathrm{H}_{0}$, and FV More Sodruzhestva were processed using a combination of Echoview (version 8.0.105.32871) and the Large Scale Survey System (LSSS, v2.6.0; Korneliussen et al., 2016) (see below for details). The data from RRS Discovery were processed using Echoview (version 8.0.105.32871), and data from FV Fu Rong Hai were processed using Echoview (version 8.0.97.32257). Where transducer drafts were not entered into the echosounder configuration prior to starting the surveys, they were applied during processing. Calibration results (gain and Sa correction), sound speed, and absorption were also set as appropriate during processing.

Data from the EK80 and ES80 transceivers installed on FV Cabo de Hornos and FV More Sodruzhestva (Table 1) were collected using the full range resolution option in the EK/ES80 software, leading to a relatively large quantity of data. To reduce the time needed to process these data in Echoview, these files were pre-processed and re-written to contain echo amplitude and split-beam angle per sample, rather than the complex valued amplitude for each transducer quadrant (this reduced data volume by a factor of 7.7 for FV Cabo de Hornos and 6.9 for FV More Sodruzhestva).

Acoustic data collected between transects and during trawling, CTD casts, and other non-transect activities were excluded from analysis using Echoview regions of type 'bad data (no data)'. Data shallower than $20 \mathrm{~m}$ were also excluded, with manual adjustments where surface noise was deeper than $20 \mathrm{~m}$ (data from FV Fu Rong Hai excluded data shallower than $15 \mathrm{~m}$ instead of $20 \mathrm{~m}$ ). When the bottom depth was greater than $250 \mathrm{~m}$, the lower echo integration depth limit was set to $250 \mathrm{~m}$. When the bottom depth was less than $250 \mathrm{~m}$, the lower depth limit was set to the bottom depth minus $5 \mathrm{~m}$. Bottom detection used the Echoview 'Best candidate line pick' along with smoothing and a gap span with manual editing where required. When the initial processing was done in LSSS, the echosounder-detected bottom was used with manual editing where required.

Background noise was removed using an automated method (De Robertis \& Higginbottom, 2007) with the minimum signal to noise ratio set to $12 \mathrm{~dB}$. Other types of noise (e.g., second bottom echoes, spike noise, bubble noise) were removed first by manual inspection and exclusion with Echoview regions of type 'bad data (empty water)' and second, for vessels that had interference-type noise in their data (all except for FV Fu Rong Hai) an interference removal algorithm (Wang et al., 2016) was applied. During this processing it was observed that very dense parts of krill swarms were erroneously removed by the noise removal algorithm. To measure the effect of this, the high-noise $S_{\mathrm{v}}$ filter threshold was changed from the original $-40 \mathrm{~dB}$ re $1 \mathrm{~m}^{-1}$ (Wang et al., 2016) to $-30 \mathrm{~dB}$ re $1 \mathrm{~m}^{-1}$ and krill density and biomass estimates recalculated.

Detection of krill swarms was undertaken using the swarms identification algorithm (Barange, 1994; Coetzee, 2000) as implemented in the Echoview template and procedure outlined by Cox et al. (2016) and Cox (2017), with the noise filter modification detailed above and the use of a single echosounder channel rather than three. This template also implemented the noise removal described above and performed echo integration as described below.

Where LSSS was used in the processing (all vessels except for RRS Discovery and FV Fu Rong Hai), it was used to manually edit the upper and lower depth limits, create regions to remove noise, and create regions to indicate off-transect data. These data were then converted into Echoview line (.evl) and region (.evr) files. Furthermore, a list of transect start and stop times and associated echosounder files was created for each vessel and used by an R-script that, transect-by-transect, loaded the appropriate echosounder files into the Echoview template, loaded the previously created line and region files, directed Echoview to process as per the template, and then exported the integrals into files for subsequent processing (EchoviewR; Harrison et al., 2015).

The acoustic backscatter at $120 \mathrm{kHz}$ was attributed to krill swarms and integrated into 1 nautical mile (nmi) sampling sections by $250 \mathrm{~m}$ deep cells and expressed as Nautical Area Scattering Coefficients (NASC, $\mathrm{m}^{-2} \mathrm{nmi}^{-2}$ ) (MacLennan et al., 2002). The swarm detection and echo-integration used only the $120 \mathrm{kHz}$ echosounder channels, an echosounder frequency that was present and operated on all vessels (Table 1) and is the preferred echointegration frequency for krill surveys (CGAMLR, 2010).

The processing steps from the Echoview-produced NASC values through to estimates of biomass are given in Supplementary material Appendix S1. The coded implementation of these is available in the publicly viewable CCAMLR Github repository (github. com/ccamlr/2019Area48Survey, release 'vl.1').

The CCAMLR 2000 krill survey reprocessing used a threefrequency dB-difference method (Demer \& Conti, 2005; CCAMLR 2010) to identify krill backscatter, rather than the swarms method used here. The effect of using swarms to estimate krill areal densities was investigated by applying the 3-frequency dB-difference method of krill target identification (Reiss et al., 2008) to the acoustic data from RV Kronprins Haakon (the only contributing ship with the necessary three operational frequencies 38,120 , and $200 \mathrm{kHz}$ ). The data were then processed through to per-transect areal density estimates using the same processing code as was used for the swarm target identification method. Conversion factors, used for converting NASC values to krill areal density, were derived from the per-stratum krill-length distributions (Supplementary material Appendix S1). The per-transect estimates of krill areal density from the swarm identification method were then compared to those from the $\mathrm{dB}$-difference method.

\section{Krill target strength model and implementation}

Krill target strength was estimated using the full Stochastic Distorted Born-Wave Approximation model (SDWBA) (Chu et al., 1993; McGehee et al., 1998; Demer \& Conti, 2003; Calise \& Skaret, 2011). We used the Matlab package SDWBApackage2010 (Calise \& Skaret, 2011) to calculate krill TS at $120 \mathrm{kHz}$ for lengths of 10 to $67 \mathrm{~mm}$ using CCAMLR recommended parameters (references within EMM-16/38; Table 3). These per-length target strength estimates were used to calculate a mean krill target strength, weighted by the length-frequency distributions measured during the 2018-19 Area 48 Survey period (denominator, eq. 2 in Supplementary material Appendix S1).

\section{Krill-length distributions}

In order to provide the best overall representation of the length-frequency distribution of krill in the survey area and at

Table 3. Parameters used in the SDWBA model to estimate krill target strength.

\begin{tabular}{lll}
\hline Parameter & Value & Source \\
\hline Number of cylinders & $14(24$ at 200 kHz $)$ & McGehee et al., 1998 \\
Krill length & 38.35 & McGehee et al., 1998 \\
Phase variability & 0.7071 & Demer \& Conti, 2005 \\
Fatness coefficient & 1.4 & Demer \& Conti, 2005 \\
Density contrast & 1.0357 & Foote, 1990 \\
Sound speed contrast & 1.0279 & Foote, 1990 \\
Sound speed in water & 1456 & herein \\
Orientation & $\mathrm{N}(-20,28)$ & SC-CAMLR-XXIX, Annex 5 \\
\hline
\end{tabular}


the time of the survey all available krill-length data collected from within the Eastern Scotia Sea, Scotia Sea and Antarctic Peninsula strata of the 2018-19 Area 48 Survey were used. Krill-length data were collected during the period of the acoustic survey on the vessels conducting the survey, from scientific observers on krill fishing vessels (CCAMLR, 2019) and from krill-dependent predators as part the CCAMLR Ecosystem Monitoring Program (Agnew, 1997; Panasiuk et al., 2020). The likelihood of selectivity of the different trawls was tested by comparing the krill-length frequencies, per vessel, to L50 lengths, where L50 is defined as the predicted krill length at which there is $50 \%$ retention probability for the codendmesh size used. The L50 values were calculated using the optimal orientation during mesh penetration (Krag et al., 2014; Macaulay et al. 2019). Only trawls where more than 20 krill were caught were utilized in this comparison. For all sampling methods, krill length (AT; Morris et al., 1988) was measured from the anterior margin of the eye to the tip of the telson to the nearest millimetre excluding the setae.

Krill-length frequencies from each of the three sampling platforms (survey vessels, fishing vessels, and predators) were equally weighted. The proportion of krill in each length class for each sampling platform was used, summing the proportions for each length class across all sampling platforms. The data were then used to create strata-specific krill-length-frequency distributions for the 1) Antarctic Peninsula, comprising the Antarctic Peninsula, South Shetland Islands, West, Elephant, Bransfield, and Joinville strata; 2) Scotia Sea comprising the Scotia Sea, South Georgia, South Orkney Islands, South Orkney Concentrated, South Orkney Fixed, and Western Core Box strata; and 3) South Sandwich Islands comprising the Eastern South Sandwich Islands and South Sandwich Islands strata (Fig. 1).

\section{Sound speed and absorption}

Seawater salinity, temperature, and depth measurements were made by all vessels, either via conductivity-temperature-depth (CTD) casts or by attaching an internally-logging CTD to trawls. These data were used to derive sound speed and acoustic absorption estimates for the entire survey area. Sound speed was calculated following Fofonoff \& Millard (1983) and absorption following
Francois \& Garrison (1982a, b) from 10 to $250 \mathrm{~m}$ (or deepest depth if shallower than $250 \mathrm{~m}$ ). The average sound speed and absorption was then derived for each CTD station, weighted by depth squared (i.e., $\mathrm{r}^{-2}$ following the CGAMLR 2000 survey analysis). The CGAMLR 2000 analysis calculated the averages using data from 10 to $500 \mathrm{~m}$, but in 2018-19 Area 48 Survey since acoustic data deeper than $250 \mathrm{~m}$ were ignored, the 2018-19 Area 48 Survey average was calculated from 10 to $250 \mathrm{~m}$.

The CCAMLR 2000 survey averaged equally across all CTD cast measurements carried out during the survey (Demer, 2004). The spatial distribution of CTD casts in 2000 was uniform (Demer, 2004: fig. 1), thereby avoiding any spatial bias to the average. The spatial distribution of the CTD measurements in the 2018-19 Area 48 Survey, however, was denser around the South Shetland Islands and South Orkney Islands than elsewhere. To reduce the bias that would result from taking an average of all stations, the per-station sound speed and absorption values were linearly interpolated onto a uniform grid with resolution $1^{\circ}$ by $1^{\circ}$ over the survey strata and the average taken from these gridded values.

The methods used and the results derived by different participates of the survey were cross-checked by the Subgroup on Acoustic Survey and Analysis Methods of SC-CAMLR (SCCAMLR, 2019a), including taking into account of the suggestions made by the Working Group on Ecosystem Monitoring and Management of SC-CAMLR on an early report of survey (SCCAMLR, 2019b).

\section{RESULTS}

\section{Survey timing}

The 2018-19 Area 48 Survey transects corresponding to those used in the CCAMLR 2000 survey were run during 13-18 December 2018 and 16 January to 2 March 2019, whereas those corresponding to the US AMLR surveys were run during 5-10 February and 8-15 March 2019 (Table 4). The majority of the transect effort was undertaken by FV Cabo de Hornos (37\%), followed by RV Kronprins Haakon (28\%), RRS Discovery (11\%), FV Kwang Fa Ho (9\%), FV Fu Rong Hai (8\%) and FV More Sodruzhestva

Table 4. Survey start and stop dates per vessel and per strata. AP, Antarctic Peninsula; ESS, Eastern Scotia Sea; SG, South Georgia; SOC, South Orkney concentrated; SOF, South Orkney fixed; SOI, South Orkney Islands; SS, Scotia Sea; SSI, South Shetland Islands; Sand, South Sandwich Islands.

\begin{tabular}{|c|c|c|c|}
\hline Vessel/stratum & Survey transects started & Survey transects ended & Total transect distance $(\mathrm{nm})$ \\
\hline FV Cabo de Hornos & 16 Jan. 2019 & 2 Mar. 2019 & 3,928 \\
\hline RRS Discovery & 26 Jan. 2019 & 7 Feb. 2019 & 1,130 \\
\hline FV Fu Rong Hai & 5 Feb. 2019 & 10 Feb. 2019 & 875 \\
\hline RV Kronprins Haakon & 18 Jan. 2019 & 15 Feb. 2019 & 2,969 \\
\hline FV Kwang Ja Ho & 8 Mar. 2019 & 15 Mar. 2019 & 940 \\
\hline FV More Sodruzhestva & 13 Dec. 2018 & 18 Dec. 2018 & 692 \\
\hline AP & 13 Dec. 2018 & 29 Jan. 2019 & 1,593 \\
\hline Bransfield Strait & 07 Feb. 2019 & 09 Feb. 2019 & 271 \\
\hline ESS & 29 Jan. 2019 & 07 Feb. 2019 & 676 \\
\hline Elephant & 05 Feb. 2019 & 12 Mar. 2019 & 725 \\
\hline Joinville & 06 Feb. 2019 & 07 Feb. 2019 & 174 \\
\hline$S G$ & 05 Feb. 2019 & 06 Feb, 2019 & 77 \\
\hline $\mathrm{soc}$ & 24 Jan. 2019 & 27 Jan, 2019 & 218 \\
\hline SOF & 22 Jan. 2019 & 31 Jan. 2019 & 676 \\
\hline SOI & 06 Feb. 2019 & 18 Feb. 2019 & 204 \\
\hline SS & 28 Jan. 2019 & 02 Mar. 2019 & 3,880 \\
\hline SSI & 16 Jan. 2019 & 20 Jan. 2019 & 385 \\
\hline Sand & 26 Jan. 2019 & 04 Feb. 2019 & 538 \\
\hline West & 12 Mar. 2019 & 15 Mar. 2019 & 404 \\
\hline
\end{tabular}


(7\%), respectively, for a total acoustic transect distance across all vessels of $10,534 \mathrm{nmi}$.

\section{Krill-length frequency}

A total of 45,650 krill-length measurements, of which $45 \%$ were from the Antarctic Peninsula strata, 54\% from the Scotia Sea strata, and 1\% from the South Sandwich Islands (Fig. 2, Table 5), were made during the period of the survey. The L50 lengths varied among trawls (Table 1), but in all cases except one (the trawl used on FV More Sodruzhestva), the L50 length did not overlap the krill-length distribution. There were 128 trawls that caught more than 20 krill, two of which were from FV More Sodruzhestva. Consequently, the effect of this potential length frequency bias is minimal. The krill-length distributions were unimodal with mean lengths of $42.5 \mathrm{~mm}$ (Scotia Sea), $46.4 \mathrm{~mm}$ (Antarctic Peninsula), and $43.1 \mathrm{~mm}$ (South Sandwich Islands) (Fig. 3).

\section{Sound speed and absorption}

Conductivity, temperature, and depth data were collected from 253 CTD casts. The sound speed was slower at higher latitudes (Fig. 4, left), driven by the lower water temperature. Absorption followed the same pattern of decreasing towards the south (Fig. 4, right).

The average sound speed was $1,456 \mathrm{~m} \mathrm{~s}^{-1}$ and absorption estimates were $10.4,27.9$, and $41.4 \mathrm{~dB} \mathrm{~km}^{-1}$ at 38,120 , and $200 \mathrm{kHz}$, respectively. The sound speed was the same as prescribed in the pre-survey documents. The absorption differed from the pre-survey documentation by $0.2 \mathrm{~dB} \mathrm{~km}^{-1}$ at most (Table 2).

\section{Calibration}

All vessels were successfully calibrated in the survey area, immediately before, during, or immediately after the survey (Table 6).

\section{Effect of night-time surveying}

There were approximately $5 \mathrm{hrs}$ of darkness per $24 \mathrm{hr}$ period and using only data collected during the day reduced the sampling effort by $20 \%$. The reduction in effort was not evenly distributed

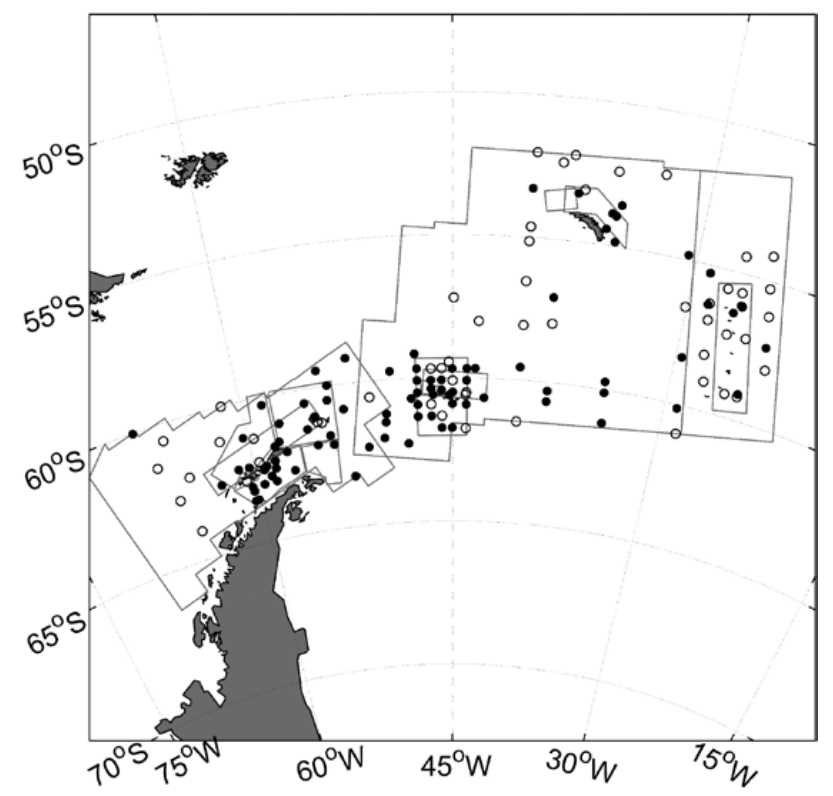

Figure 2. Locations of krill sampling trawls. Open circles indication less than 20 krill caught, filled circles more than 19 krill caught.
(Fig. 5), particularly for the smaller strata with shorter transects and those conducted later in the survey period.

The krill areal density (and biomass) tended to increase when using the day-only acoustic data (Table 8), although it decreased in the South Georgia and Bransfield Strait strata. The change for each overall survey, however, was small (last two rows in Table 8). The CV of the surveys increased (from just under $13 \%$ to just over $13 \%$ for the CCAMLR 2000 strata and from 18\% to $23 \%$ for the US AMLR strata), as would be expected by what is effectively a reduction in sampling effort. Some transects were run almost exclusively during the day (e.g., Eastern Scotia Sea, South Sandwich Islands, West, and Joinville).

\section{Effect of krill-discrimination technique}

The change in estimated biomass per stratum between the swarmbased and dB-difference discrimination techniques varied markedly between strata (Table 9). The ratios of per transect estimates of krill areal density reflected this and showed that in areas of high krill densities (in general, the on-shelf strata) the choice of discrimination method had only a minor effect on the estimated krill areal density (Fig. 6). The usage of different discrimination techniques therefore had a relatively minor effect on the estimate of total biomass. Inspection of a sample of echograms indicated that the dB-difference method included more layer-like backscatter than did the swarms method, and that these conditions were more prevalent in the large Antarctic Peninsula and Scotia Sea strata, the strata with the largest dB-difference and swarmbased differences.

\section{Effect of change in noise threshold}

Changing the $\mathrm{S}_{\mathrm{y}}$ noise filter threshold resulted in more backscatter being attributed to krill and a $15.7 \%$ increase in the estimate of total krill backscatter. Most of the additional backscatter occurred when encountering regions of high krill density (Fig. 7).

\section{Biomass estimates and geographical distribution of krill density}

The total krill biomass for the 2018-19 Area 48 Survey was 62.6 megatonnes (summing up the numbers from Tables 7 and 10) with a coefficient of variation of $13 \%$. The densities were highest on the shelf to the north of the South Shetland Islands, including Elephant Island (Fig. 8) and along the shelf north of the South Orkney Islands and south east of South Georgia (Fig. 8).

The average densities found in the 2018-19 Area 48 Survey versus the CAAMLR 2000 survey were 2.1 times higher in the Antarctic Peninsula, 13.9 times higher in the Eastern Scotia Sea, and 6.7 times higher in South Sandwich Islands. The Scotia Sea was 1.1 times higher, South Shetland 2 times higher, South Orkney 3.4 times higher, and South Georgia 5.3 times higher in the CGAMLR 2000 survey compared to the 2018-19 survey strata (Table 11). The densities for the regional scaled strata (the 48.1 and 48.2 surveys) show a different distribution pattern

Table 5. Number of krill length measurements in each of the large-scale strata from the vessels conducting the survey (Survey), from scientific observers on krill fishing vessels (Fishery), and from krill-dependent predators as part the CCAMLR Ecosystem Monitoring Program (CEMP). AP, Antarctic Peninsula; SS, Scotia Sea; ESS, East Scotia Sea.

\begin{tabular}{lccrr}
\hline & AP & SS & ESS & \\
\hline Survey & 17744 & 10454 & 629 & 28,827 \\
Fishery & 1350 & 11000 & 0 & 12,350 \\
CEMP & 1444 & 3029 & 0 & 4,473 \\
Total & 20,538 & 24,483 & 629 & \\
\hline
\end{tabular}



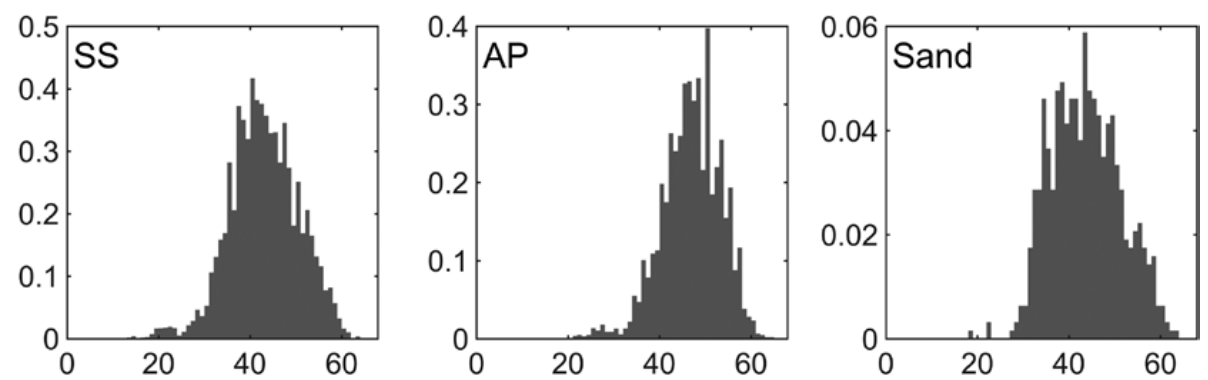

Figure 3. Spatially aggregated krill-length distributions used for the biomass estimates (SS, Scotia Sea; AP, Antarctic Peninsula; Sand, South Sandwich Islands).
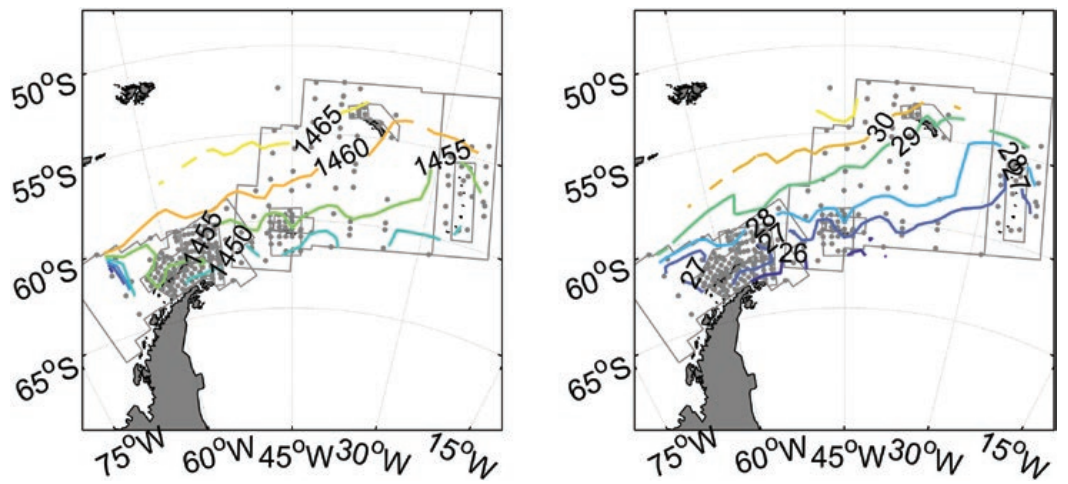

Figure 4. Location of CTD casts (grey dots) and contours of the calculated sound speed (left panel) and $120 \mathrm{kHz}$ acoustic absorption (right panel).

compared to the 2018-19 Survey strata (Figs. 8, 9) - the region of higher densities occurred to the east of Elephant Island and to a lesser degree to the northwest of the South Shetland Islands.

\section{DISGUSSION}

The 2018-19 Area 48 Survey provides an updated large-scale survey of the krill in this region. The planning of the survey design and the implementation of methods used for the analyses of krill density was accomplished through the coordination of participating members via CCAMLR and its working groups, led by Norway (Knutsen et al., 2018; Krafft et al., 2018b, c; Macaulay et al., 2018). CCAMLR provided an electronic discussion forum (e-group) to facilitate planning. Importantly, the 2018-19 Area 48 Survey demonstrated that fishing vessels can be utilized to collect acoustic and biological data on krill, and that successful cooperation between scientists and the fishing industry provides potential benefits and opportunities for generating datasets as a basis for future scientific advice on the management of Antarctic living marine resources.

The survey area stretching from the Antarctic Peninsula area to waters north of South Georgia is identified as the area in the Southern Ocean with the highest concentration of Antarctic krill (Marr, 1962; Atkinson et al., 2009). The highest krill densities from the 2018-19 Area 48 Survey strata were located on the shelf to the north of the South Shetland Islands, including the waters off Elephant Island and along the shelf north of the South Orkney Islands and south east of South Georgia. The average per strata krill densities between the CCAMLR 2000 and day-only 2018-19 Area 48 Survey differed (Table 11). The regional differences in krill densities between the two surveys undertaken 19 years apart could be attributed to natural variations in the environment and/ or the krill stock itself. For instance, temporal oscillations in krill abundance have been described with successive changes in reproductive success linked to the recruitments of strong cohorts both regionally and locally (Atkinson et al., 2004; Fielding et al., 2014).
Typically, several poor years of reproductive success are followed by one to two good years, in a repeating cycle with a four to five year period (Hewitt et al., 2003). During periods of oceanic cooling and warming, krill stocks have considerable annual variations in density, distribution and recruitment (Siegel \& Loeb, 1995; Siegel et al., 1997, 1998; Loeb et al., 1997).

Such patterns of variability are important, as the evidence for global warming is unequivocal (IPCG, 2018) and monitoring of global climate shows that the Southern Ocean has experienced warming during the second half of the twentieth century (e.g., Levitus, 2000; Gille, 2002). It has been projected that future climate-induced changes in the Southern Ocean will also drive habitat and biome shifts with a predicted southward displacement of lower trophic level organisms (Constable et al., 2014). The warming trend may also favor other macro- and mesozooplankton species that now occupy the more northerly parts of the Antarctic Circumpolar Current (Whitehouse et al., 2008). In this regard, recent studies based on historic net-survey data, report a slowly decreasing krill recruitment which has caused a reduced biomass, poleward contraction, with increases centering over Antarctic continental shelves during the last 90 yrs (Atkinson et al., 2019). Uncertainties persist, however, regarding how, or to what extent, krill respond to climate change. For example, reports on krill distribution and quantity are inconsistent, as some analyses have not detected such trends in long-term krill abundance and distribution (see Cox et al., 2018). The results from the 2018-19 Area 48 Survey indicate that the overall biomass of krill in 2019 and 2000 were similar, with some discrepancies in distribution (Fig. 9). These two datasets, representing snapshots in time are not adequate to determine change in the krill distribution, but they provide support of considerable and comparable biomass throughout the recently surveyed area. Arguably the higher densities around South Georgia in 2000 and the higher densities in the Antarctic Peninsula area in the 2018-19 Area 48 Survey could point in the direction of a southerly movement, but this does not explain e.g., the higher densities in the Eastern Scotia Sea and South Sandwich area or lower densities in the 


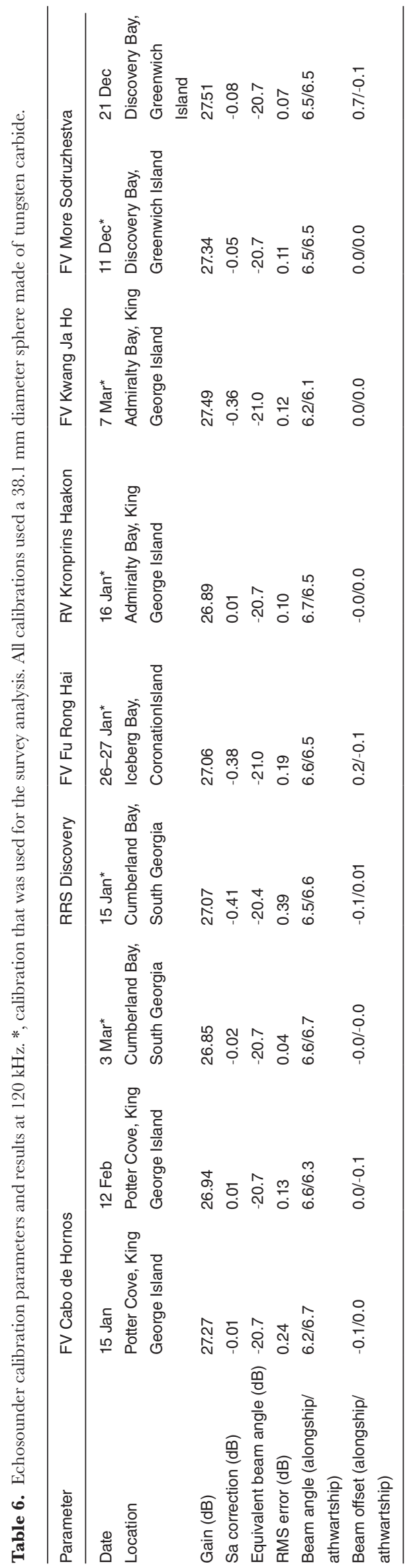

South Shetland area from the 2018-19 Area Survey. A level of spatial difference between surveys should be anticipated, given existing knowledge about krill variability (Reiss et al., 2008; Fielding et al., 2014; Krafft et al., 2018a), including within and between seasons (Reid et al., 2010). It is also timely to reiterate the fact that 'short time-series do not necessarily reveal the full complexity of environmental relationships, and that long time-series of data are needed to comprehend ecological complexity' (Fielding et al., 2014).

The main aim of the 2018-19 Area 48 Survey was to describe the current status of krill biomass and distribution and to serve as a baseline for building future timeseries of krill biomass estimates. A direct comparison to the CCAMLR 2000 survey was not a primary objective given the differences in procedures and methods between the two surveys, which requires a comprehensive error budget for both surveys (such as that detailed in Demer, 2004). This has not been done for the 2018-19 Area 48 Survey effort, but we suggest it as a desirable future work. In the absence of such an in-depth comparison both the sampling coefficient of variation $(13 \%)$ and biomass (62.6 megatonnes) suggest that the 2018-19 Area 48 Survey result is similar to the biomass estimate from the CCAMLR 2000 survey.

Salps (mainly the Salpa thompsoni Foxton, 1961), another major macrozooplankton species in this region, can co-occur in the same section of the water column as Antarctic krill (Woodd-Walker et al., 2003). They also have a frequency response similar to krill, but models of salp acoustic backscattering have been developed (Wiebe et al., 2010). We took these models into account during the scrutiny of the acoustic data from this study. A similar problem can occur with mackerel icefish (Champsocephalus gunnari Lönnberg, 1905), whereby schools of these fish can have similar characteristics as krill swarms (Fallon et al., 2016).

We cannot completely rule out that the methods used here, and all other surveys undertaken, may misinterpret some echoes as salps or icefish rather than E. superba (or vice versa), other krill species and closely related elongated crustaceans such as amphipods and mysids with similar frequency response. It should not be ruled out that potential ecosystem change through global warming could affect species interactions and changes in behavior, dispersion, aggregative characteristics, or changing depth preferences, that could directly affect how key ecosystem components are detected and quantified acoustically. This underscores the importance of obtaining biological samples along transects to validate the interpretation of acoustic data. The exclusion of the upper portion of the water column in the acoustic processing will also lead to some krill being missed (Scalabrin et al., 2009), depending on the extent of the krill diel vertical movement (Demer \& Hewitt, 1995), and is an unavoidable consequence of using large ships with hull-mounted acoustic transducers (at 4-11 m depth), the need to avoid using data from the transducer nearfields, the potential for avoidance of the vessel by organisms, and the under-sampling that occurs when small objects are very close to a moving transducer. These disadvantages can be moderated using alternative platforms (e.g., autonomous gliders or surface vehicles) that can place the transducers closer to the sea surface, but there are also additional considerations one must consider with such technology. Some of these platforms are very slow moving, which is a major disadvantage when undertaking a survey that covers vast latitudinal and longitudinal gradients, as was done during the 2018-19 Area 48 Survey. Active acoustic techniques from larger vessels currently remain the only practical krill surveying option that can synoptically sample at the scales considered here during most sea-states. Antarctic krill occurs over large parts of the Southern Ocean as thin layers, but display highly aggregative behavior during large parts of its life cycle in swarms with varying shapes and densities across the regions (e.g., Watkins \& Murray, 1998; Hamner \& Hamner, 2000; Tarling et al., 2009, Krafft et al., 2012, 2015, 2018a). As one obtains increased 


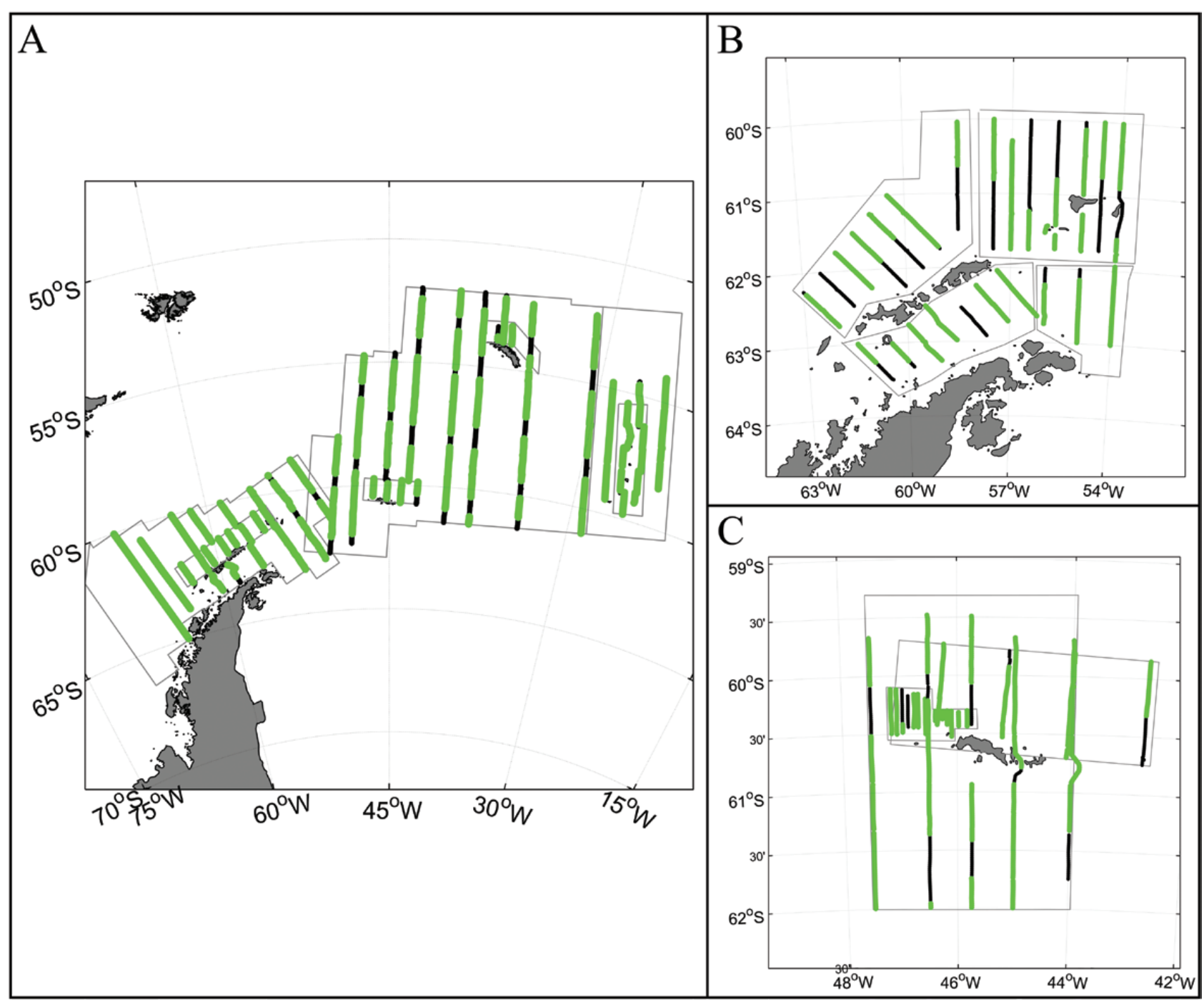

Figure 5. Daylight occurrence during the survey transects. Transect parts undertaken during the day (between civil dawn and civil dusk; green) and during the night (between civil dusk and civil dawn; black) $(\mathbf{A})$ the large-scale survey strata; the AMLR survey strata (B); the various strata around the South Orkney Islands $(\mathbf{C})$.

understanding of such behavior, this can also be considered in future planning of survey design in order to reduce potential systematic bias due to acoustic data collection coverage (cf. Miller \& Hampton, 1989). The dynamic nature of krill must also be considered; their distribution patterns change during the season and the spatial distribution of krill can be quite variable and difficult to predict. Increased understanding about advection processes is also important.

Figure 7 presents cumulative krill density after increasing the $\mathrm{S}$ noise-threshold level, which is not part of the procedures followed to produce all of the other results in this article and which were approved by the CCAMLR Scientific Committee meeting in 2019 (CCAMLR, 2019). These results are presented to demonstrate that there is still a potential to improve methods and krill biomass estimates. Given the notable difference resulting from this threshold level change and the possibility that it can give an improved estimate, we encourage future consideration of this procedure by CCAMLR.

Monitoring of krill on meso-scales within the subareas during the last two decades has been regularly performed in subarea 48.1 (Reiss et al., 2008; Kinzey et al., 2015), subarea 48.2 (Krafft et al., 2018a), and subarea 48.3 (Fielding et al., 2014). Together, the data from these three survey series could form an integrated monitoring effort extending across the SW Atlantic sector, linking the three areas with high krill concentrations and the highest fishing activity. Comparisons of the mesoscale surveys are feasible, but require significant analysis effort, especially given the different methods, survey designs, and survey areas. A comparison that also includes the overlapping large-scale survey data from this study and the CGAMLR 2000 survey will further contribute to the understanding about the implications of the methodological differences. Such future study can add further knowledge to help understand the dynamics of krill oscillatory patterns (Hewitt et al., 2003; Fielding et al., 2014; Ryabov et al., 2017), and might also help address how regions are interconnected (Brierley et al., 1999).

From the 2018-19 Area 48 Survey effort, slightly different patterns appear when comparing the regional scaled strata to the large-scale strata, with the region of higher densities concentrating more to the east of Elephant Island and to a lesser degree to the northwest of the South Shetland Islands. Such differences are expected as natural short-term variability due to seasonal changes, environmental influences, or simply the fluctuations inherent in any natural ecosystem. This also demonstrates the complexity of direct comparisons of data collected at different spatiotemporal scales (Wikle et al., 2019), from a species that can occur in highly gregarious groupings and display rapid changes in swarm configuration and location. 


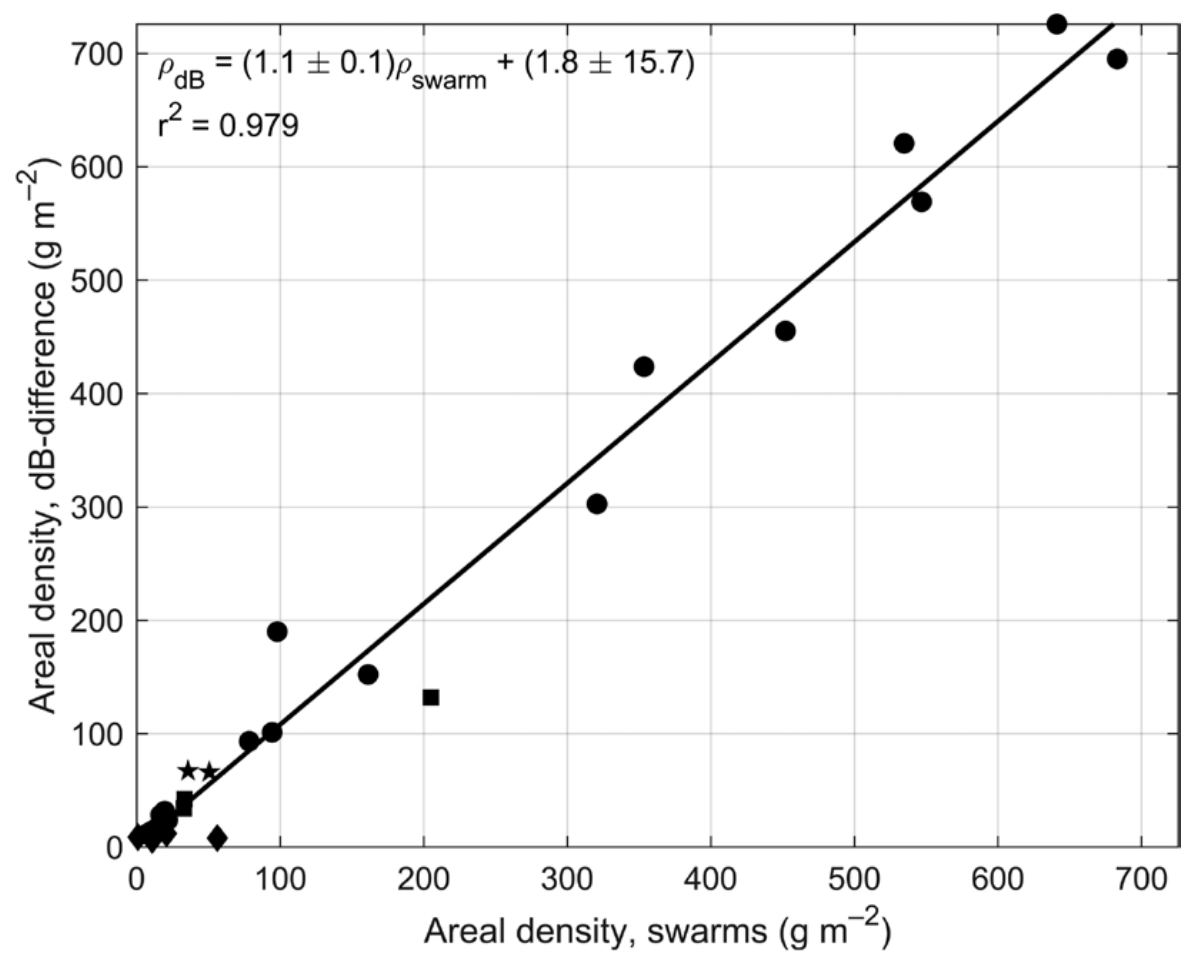

Figure 6. Regression between transect krill areal density derived from the swarm detection method and from the three-frequency dB-difference method. Symbol indicates stratum: star, Antarctic Peninsula, triangle; South Georgia Island, circle; South Orkney concentrated, square; South Orkney fixed, diamond; SS, Scotia Sea.

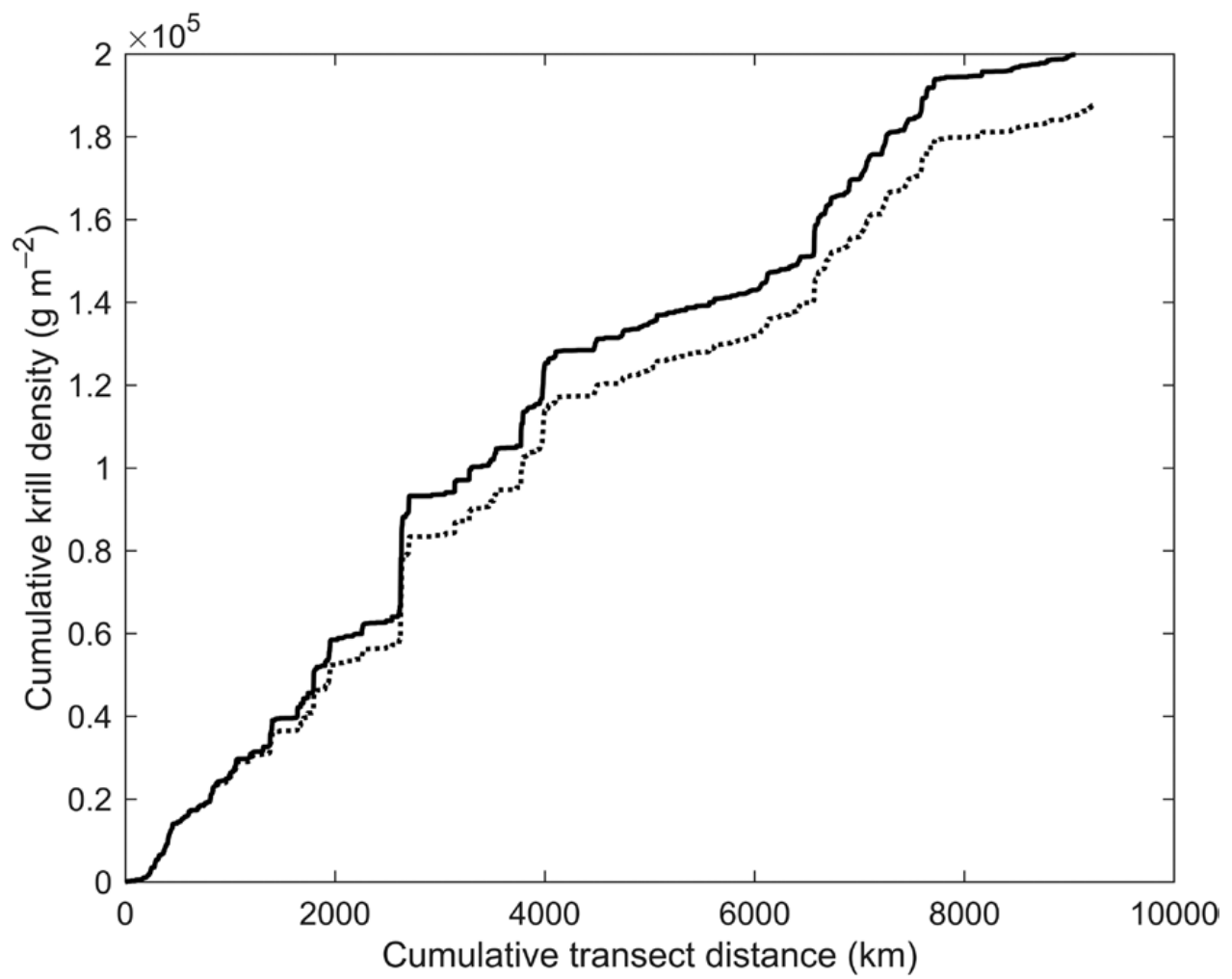

Figure 7. Cumulative krill density obtained from the southwest arms analysis when using a $-30 \mathrm{~dB}$ re $\mathrm{m}^{-1}$ (solid line) and $-40 \mathrm{~dB}$ re $\mathrm{m}^{-1}$ (dotted line) noise filter $\mathrm{S}_{\mathrm{v}}$ threshold.

The procedures used in the 2018-19 Area 48 Survey differed in several ways from the CGAMLR 2000 survey procedures. Some of these were due to operational differences between the use of research and fishing vessels (e.g., trawl type, different levels of synoptic coverage), while some were due to changes in acoustic survey best-practice (e.g., automated processing of acoustic data), 
B.A. KRAFFT ET AL.

Table 7. Mean areal krill densities, biomass estimates, and associated variances by survey and stratum.

\begin{tabular}{|c|c|c|c|c|c|}
\hline Survey/stratum & Nominal area $\left(\mathrm{km}^{2}\right)$ & Mean krill density $\left(\mathrm{g} \mathrm{m}^{-2}\right)$ & Krill biomass $(\mathrm{t})$ & Variance component $\left(10^{6} \mathrm{t}^{2}\right)$ & Survey period (2019-2020) \\
\hline \multicolumn{6}{|l|}{ "CCAMLR 2000" stratums } \\
\hline Antarctic Peninsula & 473,318 & 40.5 & $19,158,000$ & $4,432,000$ & 13 Dec.-29 Jan. \\
\hline Scotia Sea & $1,109,789$ & 25.9 & $28,742,000$ & $56,678,000$ & 28 Jan. -3 March \\
\hline Eastern Scotia Sea & 321,800 & 23.9 & $7,677,000$ & $1,555,000$ & 29 Jan. -7 Feb. \\
\hline South Shetland Islands & 48,654 & 67.7 & $3,295,000$ & 621,000 & 16 Jan.-20 Jan. \\
\hline South Orkney Islands & 24,409 & 77.8 & $1,900,000$ & 337,000 & 6 Feb.-18 Feb. \\
\hline South Georgia & 25,000 & 9.1 & 227,000 & 3,000 & 5 Feb.-6 Feb. \\
\hline South Sandwich Islands & 62,274 & 25.9 & $1,616,000$ & 68,000 & 16 Jan.-20 Jan. \\
\hline \multicolumn{6}{|l|}{ AMLR } \\
\hline Elephant & 43,865 & 56.0 & $2,458,000$ & 822,000 & 5 Feb.-12 Mar. \\
\hline West & 38,524 & 9.9 & 381,000 & 5,000 & 12 Mar.-15 Mar. \\
\hline Bransfield Strait & 24,479 & 102.4 & $2,507,000$ & 210,000 & 7 Feb.-9 Feb. \\
\hline Joinville & 18,151 & 83.0 & $1,507,000$ & 238,000 & 6 Feb.-7 Feb. \\
\hline \multicolumn{6}{|l|}{ Other } \\
\hline South Orkney concentrated & & 170.6 & & & 24 Jan.-27 Jan. \\
\hline South Orkney Fixed & & 59.0 & & & 22 Jan.-31 Jan. \\
\hline
\end{tabular}

Table 8. Proportion of krill areal density calculated from day-only acoustic data compared to day and night acoustic data.

\begin{tabular}{lc}
\hline Survey area & Proportion \\
\hline Antarctic Peninsula & 1.00 \\
Scotia Sea & 1.10 \\
Eastern Scotia Sea & 1.05 \\
South Shetland Islands & 1.01 \\
South Orkney Islands & 1.20 \\
South Georgia & 0.71 \\
South Sandwich Islands & 1.03 \\
Elephant Island & 1.13 \\
West & 1.02 \\
Bransfield Strait & 0.77 \\
Joinville Island & 1.10 \\
CCAMLR 2000 strata & $\mathbf{1 . 0 6}$ \\
AMLR strata & $\mathbf{0 . 9 8}$ \\
\hline
\end{tabular}

Table 9. Per-strata estimates of krill areal density estimated using the swarm method $\left(\rho_{\text {swarm }}\right)$ and the ratio against the density estimated from the three-frequency dB-difference method $\left(\rho_{d B}\right)$. AP, Antarctic Peninsula; SS, Scotia Sea; SG, South Georgia; SOF, South Orkney fixed; SOG, South Orkney concentrated; $n / a$, not available.

\begin{tabular}{lccc}
\hline Stratum & $\left(\rho_{\text {scaum }} \mathrm{g} \mathrm{m}^{-2}\right)$ & $\rho_{d B} / \rho_{\text {swarm. }}$ & Stratum area $\left(\mathrm{km}^{2}\right)$ \\
\hline AP & 40.5 & 1.6 & 473318 \\
SS & 25.9 & 0.4 & 1109789 \\
SG & 9.1 & 1.5 & 25000 \\
SOF & 59.0 & 0.8 & $\mathrm{n} / \mathrm{a}$ \\
SOC & 170.6 & 1.1 & $\mathrm{n} / \mathrm{a}$ \\
\hline
\end{tabular}

equipment configuration options (e.g., transmission power level), sea-ice coverage, and some technical engine problems with one of the vessels. Comparison of survey results is confounded by methodological differences. Our results show that both night sampling and krill identification method change the biomass estimate (by up to $\sim 6 \%$ and $\sim 10 \%$, respectively). We have not assessed the effects of other methodological differences.

The only other large-scale surveys performed in the SW Atlantic sector were two major multi-ship campaigns, FIBEX in 1980-1981 (El-Sayed, 1994) and SIBEX in 1983-1984 and 1984-1985 (Siegel, 1986; Trathan et al., 1993, 1995). The primary areas of these field campaigns were the Southwest Atlantic (South Georgia, South Orkneys, Antarctic Peninsula) and Indian Ocean (El-Sayed, 1994; Hosie 2012). It would be valuable in the future to reprocess these historical data to allow better comparisons with recent mesoscale and large-scale surveys; however, given the magnitude of this task, we have not compared our results with these regional surveys.

As part of the development of management options based on ecosystem process monitoring, CCAMLR's mandate requires that, amongst other things, there is consideration of potential impact of concentrated fishing effort. This is especially important, but not limited to, concentrated fishing near breeding colonies of land-breeding krill predators (Trathan et al., 2015, 2018; WarwickEvans et al., 2018). Krill is by far the most important food source for many carnivorous predators in the SW Atlantic sector (Murphy et al., 2007; Trathan \& Hill, 2016), and as such topdown ecosystem effects of prey consumption by a broad guild of krill-dependent predators must be accounted for when developing management options. Across spatio-temporal scales relevant to the guild of krill predators, it can be challenging to distinguish potential impacts from a fishery (Hilborn et al., 2018), especially when fishing mortality accounts for only a limited part of total mortality. Similarly, it can also be challenging to determine the impact of predators or natural environmental forcing on the krill stock (e.g., Atkinson et al., 2019; Cox et al., 2019). As such, within CCAMLR and indeed within the wider scientific literature, there is an active debate about the effects of the krill fishery, particularly at local scales, on a number of ecosystem components (e.g., Krüger et al., 2020; Watters et al., 2020). Identifying where and when risks to the guild of natural krill predators are likely to be more than transitory therefore remains a key challenge for management. Developing a flexible spatio-temporal management system that includes the ecological scales relevant to predators, so that concentrated fishing does not negatively impact dependent predators, requires further work. Such work is underway but will require considerable effort to ensure management is robust, especially within regions such as the Southwest Atlantic sector that are known to be affected by climate change. Continued regular and targeted monitoring, including of the krill stock, will be key, as will be the development of a suite of ecosystem and management models.

We emphasize that future regular surveys of krill should be undertaken as part of ecosystem monitoring, including by fishing vessels, as is demonstrated here. Parallel studies on the guild of 
Table 10. Krill standing stock estimates and associated variances and CV for the 2018-19 Area 48 Survey regions (following the large scale transects design based on the CCAMLR 2000 survey and the mesoscale transect design based on the AMLR surveys).

\begin{tabular}{lccccc}
\hline Survey area & $\begin{array}{c}\text { Mean } \\
\text { density }\left(\mathrm{g} \mathrm{m}^{-2}\right)\end{array}$ & $\begin{array}{c}\text { Density } \\
\text { variance }\left(\mathrm{g}^{2} \mathrm{~m}^{-4}\right)\end{array}$ & Density CV (\%) & Standing stock (t) & $\begin{array}{c}\text { Standing stock } \\
\text { variance }\left(10^{6} \mathrm{t}^{2}\right)\end{array}$ \\
\hline $\begin{array}{c}\text { Standing } \\
\text { stock CV }(\%)\end{array}$ \\
\hline CCAMLR 2000 & 30.3 & 14.9 & 13 & $62,615,000$ & $63,694,000$ \\
AMLR & 54.8 & 81.6 & 16 & $6,853,000$ & 13 \\
& & & $1,276,000$ & 16 \\
\hline
\end{tabular}
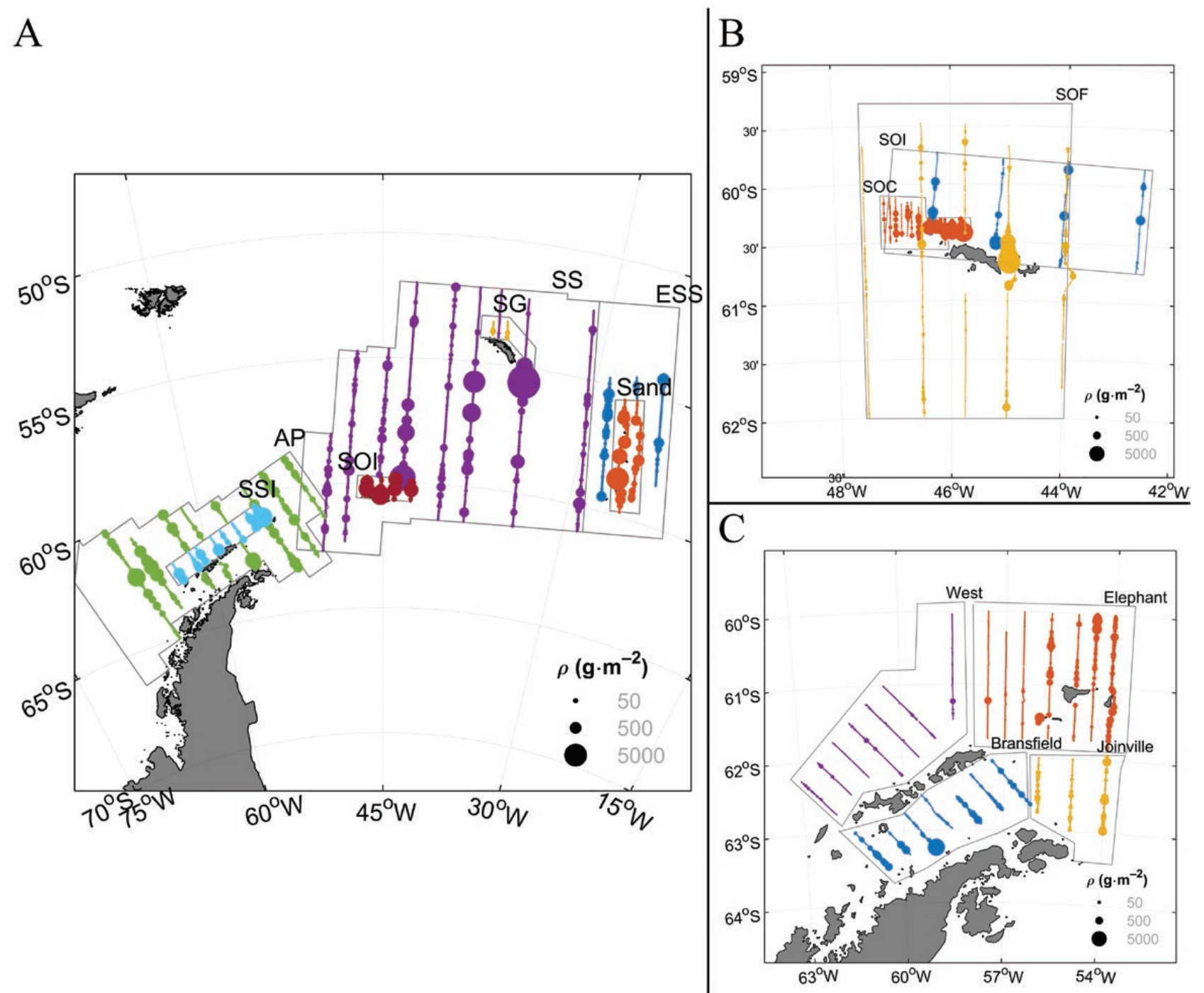

Figure 8. Krill areal density in $1 \mathrm{n}$.mi bins as observed in the large-scale survey strata in CCAMLR subareas 48.1, 48.2, 48.3, and 48.4, as are the survey strata (SS, South Shetland Islands; AP. Antarctic Peninsula; SOI, South Orkney intensive; SG, South Georgia; ESS, East Scotia Sea; Sand, South Sandwich Islands (A); the various strata around the South Orkney Islands (blue, large scale SOI stratum; orange, South Orkney fixed stratum; red, South Orkney Islands (B); AMLR survey strata (CCAMLR Subarea 48.1 covers the area south of $\left.60^{\circ} \mathrm{S}\right)(\mathbf{C})$.

krill predators, and of the environment, will also be vital. A key objective should be to identify changes to the ecosystem that are driven by natural ecosystem processes and separate those from the effects of fishing. As understanding increases, it may be feasible to develop catch limits that are variable over space and time, in response to signals determined from the ecosystem. Adjusting quotas over annual time scales will probably always remain challenging, given the requirements for management data and the logistical effort that is reasonably available; however, adjustments over sub-decadal time periods should be achievable. Further development of management methods will be key, and to develop the potential that lies in utilizing infrastructure that can be provided by the fishing industry to conduct similar surveys.

It should be noted that the fishery in the Southwest Atlantic sector of the Southern Ocean has been increasing over the last two decades, with current catch levels $\sim 3-400,000$ t year $^{-1}$; however, catches remain well below the current trigger level (620 000 $t$ year ${ }^{-1}$ across the Southwest Atlantic sector). Catches also remain well below the existing theoretical TAC of 5.6 million $t$ (Nicol et al., 2012; CCAMLR, 2016). Yet, the ecosystem is changing, which emphasize the urgency for the development of the ecosystem approach for krill fishing (Meyer et al., 2020). As part of 
Table 11. Comparison of density and biomass per strata krill between the 2010 reanalysis of the 2000 survey (Fielding et al., 2011) and day-only 2018-19 survey (using only data collected during the day).

\begin{tabular}{|c|c|c|c|c|}
\hline Stratum & 2000 survey Mean krill density $\left(\mathrm{g} \mathrm{m}^{-2}\right)$ & Krill biomass $(\mathrm{t})$ & 2018-19 survey Mean krill density $\left(\mathrm{g} \mathrm{m}^{-2}\right)$ & Krill biomass $(\mathrm{t})$ \\
\hline Scotia Sea & 31.5 & $34,928,000$ & 28.5 & $31,585,000$ \\
\hline South Shetland Islands & 136.0 & $6,615,000$ & 68.3 & $3,325,000$ \\
\hline South Orkney Islands & 319.4 & $7,797,000$ & 93.2 & $2,275,000$ \\
\hline South Georgia & 33.8 & 846,000 & 6.4 & 161,000 \\
\hline
\end{tabular}

A

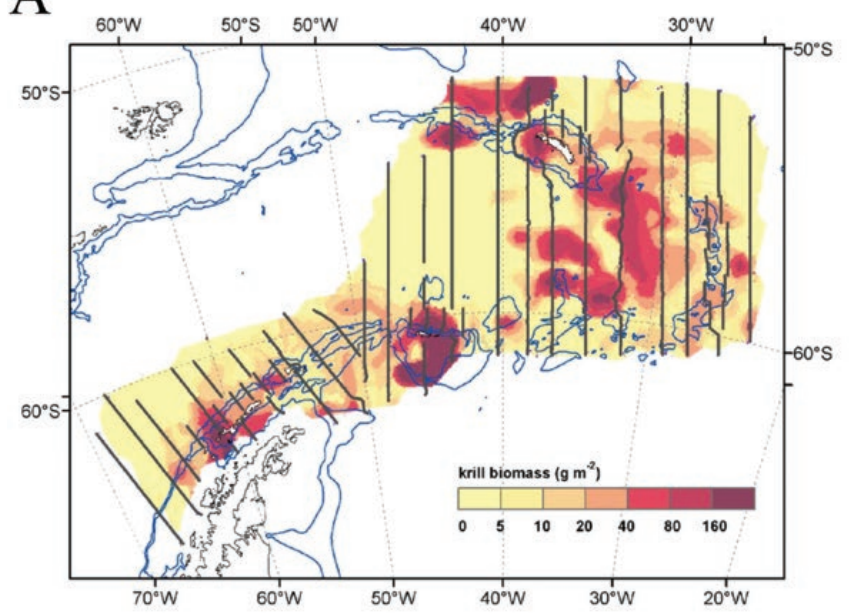

B

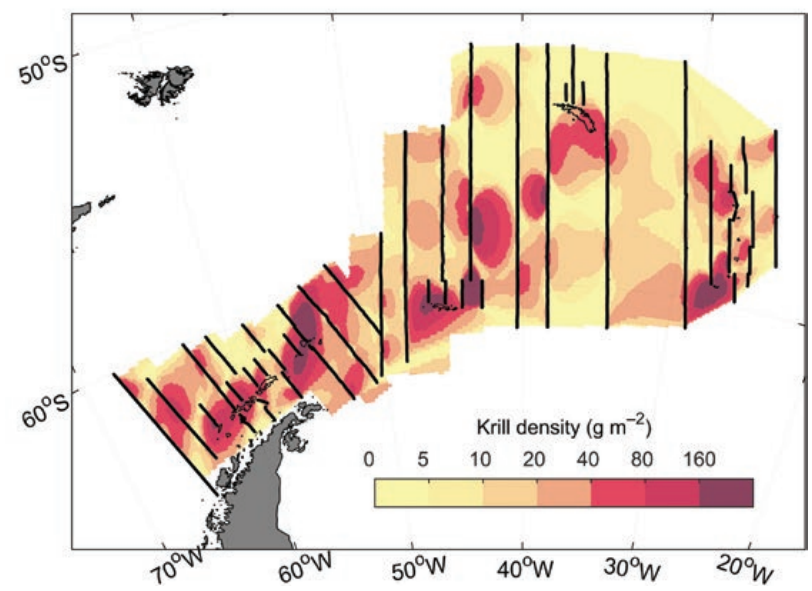

Figure 9. A visualisation of krill areal density obtained by interpolation of the 1 nmi density estimates from the 2000 (A) and 2018-19 (B) surveys. Part A was produced before the 2010 reanalysis of the 2000 survey. Part A is reprinted from Hewitt et al. (2004) with permission from the publishers.

this, our results should be an important contribution to assess any update of the CCAMLR TAC and emphasizes the importance of obtaining krill biomass data on multiple temporospatial scales that are necessary for future krill fishery management and risk assessments (SC-CAMLR, 2019b).

\section{SUPPLEMENTARY MATERIAL}

Supplementary material is available at fournal of Crustacean Biology online.

Supplementary material Appendix S1. Conversion of NASC to biomass

\section{ACKNOWLEDGEMENTS}

This work was supported by the Norwegian Ministry of Trade, Industry and Fisheries (NFD, via project number 15208), the Institute of Marine Research (IMR) and the IMR project "Krill" (project number 14246). The UK contribution was supported by the UK Research and Innovation - Natural Environment Research Council and Polar Regions Department, UK Government. The Korean contribution was supported by the National Institute of Fisheries Science (R2019021). The significant contributions by fishing vessels from China, Republic of Korea, Ukraine, the Association of Responsible Krill Harvesting Companies (ARK; www.ark-krill.org), and Aker Biomarine AS in particular are acknowledged. Without the cooperative effort of the fishing industry with national research institutions, this international effort would not have been possible to accomplish. We also thank the officers, crew, and scientific personnel onboard the vessels that carried out the surveying. We thank three anonymous reviewers for their valuable comments to the manuscript. Data used in these analyses are available on request at www.ccamlr.org.

\section{REFERENCES}

Agnew, D. 1997. The CCAMLR Ecosystem Monitoring Programme. Antarctic Science, 9: 235-242.

Atkinson, A., Hill, S.L., Pakhomov, E.A., Siegel, V., Anadon, R., Chiba, S., Daly, K.L., Downie, R., Fielding, S., Fretwell, P., Gerrish, L., Hosie, G.W., Jessopp, M.J., Kawaguchi, S., Krafft, B.A., Loeb, V., Nishikawa, J., Peat, H.J., Reiss, C.R., Ross, R.M., Quetin, L.B., Schmidt, K., Steinberg, D.K., Roshni, C.S. \& Ward, P. 2017. KRILLBASE: a circumpolar database of Antarctic krill and salp numerical densities, 1926-2016. Earth System Science Data, 9: 193-210.

Atkinson, A., Hill, S.L., Pakhomov, E.A., Siegel, V., Reiss, C.S., Loeb, V.J., Steinberg, D.K., Schmidt, K., Tarling, G.A., Gerrish, L. \& Sailley, S.F. 2019. Krill (Euphausia superba) distribution contracts southward during rapid regional warming. Nature Climate Change, 9: 142-147.

Atkinson, A., Siegel, V., Pakhomov, E.A., Jessopp, M.J. \& Loeb, V. 2009. A re-appraisal of the total biomass and annual production of Antarctic krill. Deep Sea Research Part I: Oceanographic Research Papers, 56: 727-740.

Atkinson, A., Siegel, V., Pakhomov, E. \& Rothery, P. 2004. Long-term decline in krill stock and increase in salps within the Southern Ocean. Nature, 432: 100-103.

Baker, A. de C., Clarke, M.R. \& Harris, M.J. 1973. The N.I.O. combination net (RMT $1+8$ ) and further developments of rectangular midwater trawls. Fournal of the Marine Biological Association of the United Kingdom, 53: 167-184.

Barange, M. 1994. Acoustic identification, classification and structure of biological patchiness on the edge of the Agulhas Bank and its relation to frontal features. South African Fournal of Marine Science, 14: 333-347. 
Brierley, A.S., Demer, D.A., Watkins, J.L. \& Hewitt, R.P. 1999. Concordance of interannual fluctuations in acoustically estimated densities of Antarctic krill around South Georgia and Elephant Island: biological evidence of same-year teleconnections across the Scotia Sea. Marine Biology, 134: 675-681.

Calise, L. \& Skaret, G. 2011. Sensitivity investigation of the SDWBA Antarctic krill target strength model to fatness, material contrasts and orientation. CCAMLR Science, 18: 97-122.

CCAMLR (Convention on the Conservation of Antarctic Marine Living Resources). 2010. Report of the 29th meeting of the scientific committee, Hobart, TAS, Australia, 25-29th October, 2010 SC-CGAMLR- XXIX. CGAMLR, Hobart, TAS, Australia.

CCAMLR (Convention on the Conservation of Antarctic Marine Living Resources). 2016. Report of the 35th meeting of the scientific committee, Hobart, TAS, Australia, 17-21st October, 2016. SC-CCAMLRXXXV. CCAMLR, Hobart, TAS, Australia.

CCAMLR (Convention on the Conservation of Antarctic Marine Living Resources). 2017. Report of the 36th meeting of the scientific committee, Hobart, Australia, 16-20th October, 2017. SC-CCAMLRXXXVI. CGAMLR, Hobart, TAS, Australia.

CCAMLR (Convention on the Conservation of Antarctic Marine Living Resources). 2019. Report of the 38th meeting of the scientific committee, Hobart, TAS, Australia, 21-25th October, 2019. SC-CGAMLR- XXXVIII. CCAMLR, Hobart, TAS, Australia.

Chu, D., Foote, K.G. \& Stanton, T.K. 1993. Further analysis of target strength measurements of Antarctic krill at 38 and $120 \mathrm{kHz}$ : Comparison with deformed cylinder model and inference or orientation distribution. Fournal of the Acoustical Society of America, 93: 2985-2988.

Coetzee, J. 2000. Use of a shoal analysis and patch estimation system (SHAPES) to characterise sardine schools. Aquatic Living Resources, 13: $1-10$.

Constable, A.J. \& de la Mare, W.K. 1996. A generalised model for evaluating yield and the long-term status of fish stocks under conditions of uncertainty. CCAMLR Science, 3: 31-54.

Constable, A.J. \& Nicol, S. 2002. Defining smaller-scale management units to further develop the ecosystem approach in managing large-scale pelagic krill fisheries in Antarctica. CCAMLR Science, 9: 117-131.

Constable, A.J., Melbourne-Thomas, J., Corney, S.P., Arrigo, K.R., Barbraud, C., Barnes, D.K.A., Bindoff, N.L., Boyd, P.W., Brandt, A., Costa, D.P., Davidson, A.T., Ducklow, H.W., Emmerson, L., Fukuchi, M., Gutt, J., Hindell, M.A., Hofmann, E.E., Hosie, G.W., Iida, T., Jacob, S., Johnston, N.M., Kawaguchi, S., Kokubun, N., Koubbi, P., Lea, M.A., Makhado, A., Massom, R.A., Meiners, K., Meredith, M.P., Murphy, E.J., Nicol, S., Reid, K., Richerson, K., Riddle, M.J., Rintoul, S.R., Smith, W.O., Southwell, C., Stark, J.S., Sumner, M., Swadling, K.M., Takahashi, K.T., Trathan, P.N., Welsford, D.C., Weimerskirch, H., Westwood, K.J., Wienecke, B.C., Wolf-Gladrow, D., Wright, S.W., Xavier, J.C. \& Ziegler, P. 2014. Climate change and Southern Ocean ecosystems I: how changes in physical habitats directly affect marine biota. Global Change Biology, 20: 3004-3025.

Cox, M.J. 2017. Describing krill: swarms or integration intervals? Document SG-ASAM-17/02, pp. 1-10. CCAMLR, Hobart, TAS, Australia.

Cox, M.J., Candy, S., de la Mare, W.K., Nicol, S., Kawaguchi, S. \& Gales, N. 2018. No evidence for a decline in the density of Antarctic krill Euphausia superba Dana, 1850, in the Southwest Atlantic sector between 1976 and 2016. Fournal of Crustacean Biology, 38: 656-661.

Cox, M.J., Candy, S., de la Mare, W.K., Nicol, S., Kawaguchi, S. \& Gales, N. 2019. Clarifying trends in the density of Antarctic krill Euphausia superba Dana, 1850 in the South Atlantic. A response to Hill et al. Fournal of Crustacean Biology, 39: 323-327.

Cox, M. J., Fielding, S. \& Constable, A. 2016. A procedure for krill density estimation. Document SG-ASAM-16/01, pp. 1-21. CCAMLR, Hobart, TAS, Australia.

De Robertis, A. \& Higginbottom, I. 2007. A post-processing technique to estimate the signal-to-noise ratio and remove echosounder background noise. ICES Fournal of Marine Science, 64: 1282-1291.

Demer, D.A. 2004. An estimate of error for the CGAMLR 2000 survey estimate of krill biomass. Deep Sea Research Part II: Topical Studies in Oceanography, 51: 1237-1251.

Demer, D.A. \& Conti, S.G. 2003. Reconciling theoretical versus empirical target strengths of krill: effects of phase variability on the distorted-wave Born approximation. ICES Fournal of Marine Science, 60: $429-434$
Demer, D.A. \& Conti, S.G. 2005. New target-strength model indicates more krill in the Southern Ocean. ICES Journal of Marine Science, 62 : 25-32.

Demer, D.A. \& Hewitt, R.P. 1995. Bias in acoustic biomass estimates of Euphausia superba due to diel vertical migration. Deep Sea Research Part I, 42: 455-461.

Demer, D.A., Berger, L., Bernasconi, M., Boswell, K.M., Chu, D., Domokos, R., Dunford, A.J., Fässler, S.M.M., Gauthier, S., Hufnagle, L.T., Jech, J.M., Bouffant, N., Lebourges-Dhaussy, A., Lurton, X., Macaulay, G.J., Perrot, Y., Ryan, T.E., Parker-Stetter, S., Stienessen, S., Weber, T.G. \& Williamson, N.J. 2015. Calibration of acoustic instruments. ICES Cooperative Research Report No. 326 No. 326 [https://doi.org/10.1121/10.0001498]

El-Sayed, S. (ed.). 1994. Southern Ocean Ecology: The BIOMASS Perspective. Cambridge University Press, Cambridge, UK

Fallon, N.G., Fielding, S. \& Fernandes, P.G. 2016. Classification of Southern Ocean krill and icefish echoes using random forests. ICES fournal of Marine Science, 73: 1998-2008.

Fielding, S., Watkins, J.L., Cossio, A., Reiss, C., Watters, G., Calise, L., Skaret, G., Takao, Y., Zhao, X., Agnew, D., Ramm, D., Reid, K. 2011. The ASAM 2010 assessment of krill biomass for Area 48 from the Scotia Sea CCAMLR 2000 synoptic survey. Document WG-EMM-11/20, pp. 1-10 pp. CCAMLR, Hobart, TAS, Australia.

Fielding, S., Watkins, J.L., Trathan, P.N., Enderlein, P., Waluda, C.M., Stowasser, G., Tarling, G.A. \& Murphy, E.J. 2014. Interannual variability in Antarctic krill (Euphausia superba) density at South Georgia, Southern Ocean: 1997-2013. ICES Fournal of Marine Science, $\mathbf{7 1}$ 2578-2588.

Fofonoff, P. \& Millard, R. 1983. Algorithms for computation of fundamental properties of seawater. UNESCO Technical Papers in Marine Science, 44: [http://hdl.handle.net/11329/109].

Francois, R.E. \& Garrison, G.R. 1982a. Sound absorption based on ocean measurements. Part I: Pure water and magnesium sulphate contributions. Fournal of the Acoustical Society of America, 72: 896-907.

Francois, R.E. \& Garrison, G.R. 1982b. Sound absorption based on ocean measurements. Part II: Boric acid contribution and equation for total absorption. Fournal of the Acoustical Society of America, 72: 1879-1890.

Gille, S.T. 2002. Warming of the Southern Ocean since the 1950s. Science, 295: 1275-1277.

Hamner, W.M. \& Hamner, P.P. 2000. Behavior of Antarctic krill (Euphausia superba): schooling, foraging, and antipredatory behavior. Canadian Fournal of Fisheries and Aquatic Sciences, 57: 192-202.

Harrison, L.-M.K., Cox, M.J., Skaret, G. \& Harcourt, R. 2015. The R package EchoviewR for automated processing of active acoustic data using Echoview. Frontiers in Marine Science, 2 [https://doi.org/10.3389/ fmars.2015.00015].

Hewitt, R.P. \& Low, E.H.L. 2000. The fishery on Antarctic krill: Defining an ecosystem. Approach to management. Revieres in Fisheries Science, $\mathbf{8}$ 235-298.

Hewitt, R.P., Demer, D.A. \& Emery, J.H. 2003. An 8-year cycle in krill biomass density inferred from acoustic surveys conducted in the vicinity of the South Shetland Islands during the austral summers of 19911992 through 2001-2002. Aquatic Living Resources, 16: 205-213.

Hewitt, R.P., Watkins, J., Naganobu, M., Sushin, V., Brierley, A.S., Demer, D., Kasatkina, S., Takao, Y., Goss, C., Malyshko, A. Brandon, M., Kawaguchi, S., Siegel, V., Trathan, P., Enery, J., Everson, I. \& Miller, D. 2004. Biomass of Antarctic krill in the Scotia Sea in January/February 2000 and its use in revising an estimate of precautionary yield. Deep Sea Research Part II: Topical Studies in Oceanography, 51: 1215-1236.

Heywood, B.G., A.S. Brierley \& S.F. Gull. 2006. A quantified Bayesian Maximum Entropy estimate of Antarctic krill abundance across the Scotia Sea and in small-scale management units from the CCAMLR-2000 Survey. CCAMLR Science, 13: 97-116.

Hilborn, R., Amoroso, R.O., Bogazzi, E., Jensen, O.P., Parma, A.M., Szuwalski, C. \& Walters, G.J. 2018. When does fishing forage species affect their predators? Fisheries Research, 206: 309-309.

Hill, S.L., Atkinson, A., Darby, C., Fielding, S., Krafft, B.A., Godø, O.R., Skaret, G., Trathan, P. \& Watkins, J. 2016. Is current management of the Antarctic krill fishery in the Atlantic sector of the Southern Ocean precautionary? CCAMLR Science, 23: 31-51.

Hill, S. L., Atkinson, A., Pakhomov, E.A. \& Siegel, V. 2019. Evidence for a decline in the population density of Antarctic krill Euphausia superba still stands. A comment on Cox et al. Fournal of Crustacean Biology, $\mathbf{3}$ 316-322. 
Hosie, G. 2012. Nella Dan: SIBEX II Cruise - Krill and zooplankton data, Ver. 1, Australian Antarctic Data Centre [https://www.ipcc.ch/site/assets/ uploads/sites/2/2019/06/SR15_Full_Report_High_Res.pdf].

IPCC. 2018. Global warming of $1.5^{\circ} \mathrm{C}$. An IPCC Special Report on the impacts of global warming of $1.5^{\circ} \mathrm{C}$ above pre-industrial levels and related global greenhouse gas emission pathways, in the context of strengthening the global response to the threat of climate change, sustainable development, and efforts to eradicate poverty. [www.ipcc.ch/sr15/download/].

Kinzey, D., Watters, G.M. \& Reiss, C.S. 2015. Selectivity and two biomass measures in an age-based assessment of Antarctic krill (Euphausia superba). Fisheries Research, 168: 72-84.

Knutsen, T., Krafft, B., Renner, A., Macaulay, G.J. \& Bergstad, O.A. 2018. Protocols for trawl sampling, recording of biological data, and hydrography for the 2019 International synoptic krill survey in Area 48. Document WG-EMM-18/23. CCAMLR, Hobart, TAS, Australia.

Korneliussen, R.J., Heggelund, Y., Macaulay, G.J., Patel, D., Johnsen, E. \& Eliassen, I.K. 2016. Acoustic identification of marine species using a feature library. Methods in Oceanography, 17: 187-205.

Krafft, B.A., Bergstad, O.A., Knutsen, T., Skaret, G. \& Macaulay, G. 2018b. Multinational large scale krill synoptic survey in CCAMLR Area 48 in 2019-survey plan and protocol for consideration by SG-ASAM 2018. Document SG-ASAM-18/07. CGAMLR, Hobart, TAS, Australia.

Krafft, B.A., Krag, L.A., Knutsen, T., Skaret, G., Jensen, K.H.M., Krakstad, J.O., Larsen, S.H., Melle, W., Iversen, S.A. \& Godø, O.R. 2018a. Summer distribution and demography of Antarctic krill Euphausia superba Dana, 1850 (Euphausiacea) at the South Orkney Islands, 2011-2015. Fournal of Crustacean Biology, 38: 682-688.

Krafft, B.A., Lowther, A., Macaulay, G., Chierici, M., Biuw, M., Renner, A., Klevjer, T., Øyerhamn, R., Cardenas, C., Makhado, A., Reiss, C. \& Bergstad, O.A. 2018c. Development of methods relevant to feedback management (FBM) for the krill fishery. Document WG-EMM-18/08. CCAMLR, Hobart, TAS, Australia.

Krafft, B.A., Skaret, G. \& Knutsen, T. 2015. An Antarctic krill (Euphausia superba) hotspot - population characteristics, abundance and vertical structure explored from a krill fishing vessel. Polar Biology, 38: 1687-1700.

Krafft, B.A., Skaret, G., Knutsen, T., Melle, W., Klevjer, T. \& Søiland, H. 2012. Antarctic krill swarm characteristics in the Southeast Atlantic sector of the Southern Ocean. Marine Ecology Progress Series, 465: 69-83.

Krag, L.A., Herrmann, B., Iversen, S.A., Engås, A., Nordrum, S. \& Krafft, B.A. 2014. Size selection of Antarctic krill (Euphausia superba) in trawls. PLoS ONE, 9: e102168 [https://doi.org/10.1371/journal. pone.0102168]

Krüger, L., Huerta M.F., Santa Cruz, F. \& Cardenas, C.A. 2020. Antarctic krill fishery effects over penguin populations under adverse climate conditions: Implications for the management of fishing practices. Ambio [https://doi.org/10.1007/s13280-020-01386-w].

Levitus, S. 2000. Warming of the World Ocean. Science, 287: $2225-2229$

Loeb, V., Siegel, V., Holm-Hansen, O., Hewitt, R., Fraser, W., Trivelpiece, W. \& Trivelpiece, S. 1997. Effects of sea-ice extent and krill or salp dominance on the Antarctic food web. Nature, 387: 897-900.

Macaulay, G.J., Skaret, G., Knutsen, T., Bergstad, O.A. \& Krafft, B. 2018. Acoustic manual for the krill synoptic survey in 2019. Document WG-EMM-18/12. CCAMLR, Hobart, TAS, Australia.

Macaulay, G., Skaret, G., Knutsen, T. \& Krafft, B. 2019. Methodological aspects of the International Synoptic Krill Survey in Area 48, 2019. Document WG-EMM-18/12. CCAMLR, Hobart, TAS, Australia.

MacLennan, D.N., Fernandes, P. \& Dalen, J. 2002. A consistent approach to definitions and symbols in fisheries acoustics. ICES fournal of Marine Science, 59: 365-369.

Marr, J.W.S. 1962. The natural history and geography of the Antarctic krill (Euphausia superba Dana), Cambridge University Press, Cambridge, UK

McGehee, D.E., O’Driscoll, R.L. \& Traykovski, L.V.M. 1998. Effects of orientation on acoustic scattering from Antarctic krill at $120 \mathrm{kHz}$. Deep Sea Research Part II: Topical Studies in Oceanography, 45: 1273-1294.

Meeus, J. 1998. Astronomical algorithms. Willmann-Bell, Richmond, VA, USA.

Meyer, B., Atkinson, A., Bernard, K.S., Brierley, A.S., Driscoll, R., Hill, S.L., Marschoff, E., Maschette, D., Perry, F.A., Reiss, G.S., Rombolá, E., Tarling, G.A., Thorpe, S.E., Trathan, P.N., Zhu, G. \& Kawaguchi, S. 2020. Successful ecosystem-based management of Antarctic krill should address uncertainties in krill recruitment, behaviour and ecological adaptation. Communication Earth \& Environment, 1 28 [https://doi.org/10.1038/s43247-020-00026-1].
Miller, D.G.M. \& Hampton, I. 1989. Biology and ecology of the Antarctic krill, Euphausia superba Dana: a review. BIOMASS Scientific Series, 9. $1-166$.

Morris, D.J., Watkins, J.L., Ricketts, C., Buchholz, F. \& Priddle, J. 1988. An assessment of the merits of length and weight measurements of Antarctic krill Euphausia superba. British Antarctic Survey Bulletin, 79: 27-50.

Murphy, E.J., Watkins, J.L., Trathan, P.N., Reid, K., Meredith, M.P., Thorpe, S.E., Johnston, N.M., Clarke, A., Tarling, G.A., Collins, M.A., Forcada, J., Shreeve, R.S., Atkinson, A., Korb, R., Whitehouse, M.J., Ward, P., Rodhouse, P.G., Enderlein, P., Hirst, A.G., Martin, A.R., Hill, S.L., Staniland, I.J., Pond, D.W., Briggs, D.R., Cunningham, N.J. \& Fleming, A.H. 2007. Spatial and temporal operation of the Scotia Sea ecosystem: a review of large-scale links in a krill centred food web. Philosophical Transaction of the Royal Society B: Biological Sciences, 362 $113-148$

Nicol, S., Foster, J. \& Kawaguchi, S. 2012. The fishery for Antarctic krill recent developments. Fish and Fisheries, 13: 30-40.

Panasiuk, A., Wawrzynek-Borejko, J., Musia, A. \& Korczak-Abshire, M. 2020. Pygoscelis penguin diets on King George Island, South Shetland Islands, with a special focus on the krill Euphausia superba. Antarctic Science, 32: 21-28.

Reid, K., Watkins, J.L., Murphy, E.J., Trathan, P.N., Fielding, S. \& Enderlein, P. 2010. Krill population dynamics at South Georgia: implications for ecosystem-based fisheries management. Marine Ecology Progress Series, 399: 243-252.

Reiss, C.S., Cossio, A.M., Loeb, V. \& Demer, D.A. 2008. Variations in the biomass of Antarctic krill (Euphausia superba) around the South Shetland Islands, 1996-2006. ICES Fournal of Marine Science, 65 497-508.

Roe, H. S. J. \& Shale, D. M. 1979. A new multiple rectangular midwater trawl (RMT $1+8 \mathrm{M}$ ) and some modifications to the institute of oceanographic sciences' RMT 1+8. Marine Biology, 50: 283-288.

Ryabov, A.B., de Roos, A.M., Meyer, B., Kawaguchi, S. \& Blasius, B. 2017. Competition-induced starvation drives large-scale population cycles in Antarctic krill. Nature Ecology \& Evolution, 1: 0177 [https://doi. org/10.1038/s41559-017-0177]

Scalabrin, C., Marfia, C. \& Boucher, J. 2009. How much fish is hidden in the surface and bottom acoustic blind zones? ICES Journal of Marine Science, 66: 1355-1363.

SC-CAMLR. 2018. International synoptic krill survey in Area 48, 2019; update of transect design based on proposed modifications developed during WG-EMM 2018. Document SG-CAMLR-XXXVII/12. GCAMLR, Hobart, TAS, Australia.

SC-CAMLR. 2019a. Report of the Meeting of the Subgroup on Acoustic Survey and Analysis Methods, Bergen, Norway, 26-30 August, 2019. In: Report of the Thirty-eighth Meeting of the Scientific Committee (SC-CAMLR-38), Annex 6, pp. 251-276. CGAMLR, Hobart, TAS, Australia.

SC-CAMLR. 2019b. Report of the Working Group on Ecosystem Monitoring and Management, Concarneau, France, 24 June to 5 July 2019. In: Report of the Thirty-eighth Meeting of the Scientific Committee (SC-CAMLR-38), Annex 5, pp. 171-250. CCAMLR, Hobart, TAS, Australia.

Siegel, V. 1986. Structure and composition of the Antarctic krill stocks in the Bransfield Strait Antarctic Peninsula during the second International BIOMASS Experiment (SIBEX). Fischereiwiss (Beih 1), 37: $51-72$.

Siegel, V. \& Loeb, V. 1995. Recruitment of Antarctic krill Euphausia superba and possible causes for its variability. Marine Ecology Progress Series, 123: 45-56.

Siegel, V., De La Mare, W.K. \& Loeb, V. 1997. Long-term monitoring of krill recruitment and abundance indices in the Elephant Island area (Antarctic Peninsula). CCAMLR Science, 4: 19-35.

Siegel, V., Loeb, V. \& Gröger, J. 1998. Krill (Euphausia superba) density, proportional and absolute recruitment and biomass in the Elephant Island region (Antarctic Peninsula) during the period 1977 to 1997. Polar Biology, 19: 393-398.

Tarling, G. A., Klevjer, T., Fielding, S., Watkins, J., Atkinson, A., Murphy, E., Korb, R., Whitehouse, M. \& Leaper, R. 2009. Variability and predictability of Antarctic krill swarm structure. Deep-Sea Research Part I, 56: 1994-2012.

Trathan, P.N. \& Hill, S.L. 2016. The importance of krill predation in the Southern Ocean. In: Biology and ecology of Antarctic krill (V. Siegel, ed.), pp. 321-350. Springer, Berlin. 
Trathan, P.N., Agnew, D., Miller, D.G.M., Watkins, J.L., Everson, I., Thorley, M.R., Murphy, E.J., Murray, A.W.A. \& Goss, C. 1993. Krill biomass in Area 48 and Area 58: Recalculation of FIBEX Data. SC-CAMLR-SSP/9 WG-KRILL-92, 20: 157-181.

Trathan, P.N., Everson, I., Miller, D.G.M., Watkins, J.L. \& Murphy, E.J. 1995. Krill biomass in the Atlantic. Nature, 367: 201-202.

Trathan, P.N., García-Borboroglu, P., Boersma, D., Bost, C.-A., Crawford, R.J.M., Crossin, G.T., Cuthbert, R.J., Dann, P., Davis, L.S., De La Puente, S., Ellenberg, U., Lynch, H. J., Mattern, T., Pütz, K., Seddon, P.J., Trivelpiece, W. \& Wienecke, B. 2015. Pollution, habitat loss, fishing, and climate change as critical threats to penguins. Conservation Biology, 29: 31-41.

Trathan, P.N., Warwick-Evans, V., Hinke, J.T., Young, E.F., Murphy, E.J., Carneiro, A.P.B., Dias, M.P., Kovacs, K.M., Lowther, A.D., Godo, O.R., Kokubun, N., Kim, J.H., Takahashi, A. \& Santos, M. 2018. Managing fishery development in sensitive ecosystems: identifying penguin habitat use to direct management in Antarctica. Ecosphere, 9: e02392 [https://doi.org/10.1002/ecs2.2392].

Trathan, P.N., Watkins, J.L., Murray. A.W.A., Hewitt, R.P., Naganobu, M., Sushin, V., Brierley, A.S., Demer, D., Everson, I., Goss, C., Hedley, S., Katsakina, S., Kawaguchi, S., Kim, S., Pauly, T., Priddle, J., Reid, K. \& Ward, P. 2001. The CCAMLR-2000 krill synoptic survey; a description of the rationale and design. CCAMLR Science, $\mathbf{8}: 1-24$.

Wang, X., Zhang, J. \& Zhao, X. 2016. A post-processing method to remove interference noise from acoustic data collected from Antarctic krill fishing vessels. CCAMLR Science, 23: 17-30.

Warwick-Evans, V., Ratcliffe, N., Lowther, A.D., Manco, F., Ireland, L., Clewlow, H.L. \& Trathan, P.N. 2018. Using habitat models for chinstrap penguins Pygoscelis antarctica to advise krill fisheries management during the penguin breeding season. Diversity and Distributions, 24 $1756-1771$
Watkins, J. L. \& Murray, A. W. A. 1998. Layers of Antarctic krill: are they just long krill swarms? Marine Biology, 131: 237-247.

Watkins, J.L., Hewitt, R., Naganobu, M. \& Sushin, V. 2004. The CCAMLR 2000 Survey: a multinational, multi-ship biological oceanography survey of the Atlantic sector of the Southern Ocean. Deep Sea Research Part II: Topical Studies in Oceanography, 51: 1205-1213.

Watters, G.M., Hill, S.L., Hinke, J.T., Matthews, J. \& Reid, K. 2013. Decision-making for ecosystem-based management: evaluating options for a krill fishery with an ecosystem dynamics model. Ecological Applications, 23: 710-725.

Watters, G.M., Hinke, J.T. \& Reiss. C.S. 2020. Long-term observations from Antarctica demonstrate that mismatched scales of fisheries management and predator-prey interaction lead to erroneous conclusions about precaution. Scientific Reports, 10: 2314 [https://doi.org/10.1038/s41598-020-59223-9].

Whitehouse, M.J., Meredith, M.P., Rothery, P., Atkinson, A., Ward, P. \& Korb, R.E. 2008. Rapid warming of the ocean around South Georgia Southern Ocean, during the 20th century: Forcings, characteristics and implications for lower trophic levels. Deep Sea Research Part I: Oceanographic Research Papers, 55: 1218-1228.

Wikle, C.K., Zammit-Mangion, A. \& Cressie, N.A.G. 2019. Spatio-temporal statistics with $R$. Chapman \& Hall/CRC Press, Boca Raton, FL, USA

Wiebe, P.H., Chu, D., Kaartvedt, S., Hundt, A., Melle, W., Ona, E. \& Batta-Lona, P. 2010. The acoustic properties of Salpa thompsoni. ICES Journal of Marine Science, 67: 583-593.

Woodd-Walker, R.S., Walkins, J.L. \& Brierley, A.S. 2003. Identification of Southern Ocean acoustic targets using aggregation backscatterer and shape characteristics. ICES Fournal of Marine Science, 60: 641-649.

Zerbini, A.N., Adams, G., Best, J., Clapham, P.J., Jackson, J.A. \& Punt, A.E. 2019. Assessing the recovery of an Antarctic predator from historical exploitation. Royal Society Open Science, 6: [https:// royalsocietypublishing.org/doi/10.1098/rsos. 190368]. 